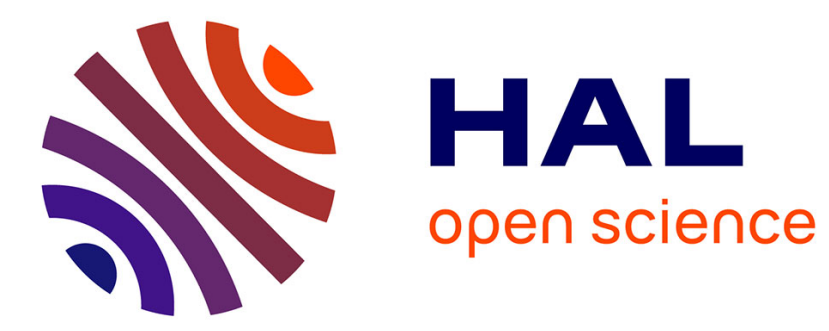

\title{
La belle dame sans merci : les fantômes médiévaux à l'âge moderne
}

\author{
François Lachaud
}

\section{To cite this version:}

François Lachaud. La belle dame sans merci: les fantômes médiévaux à l'âge moderne. Cahiers d'Extrême-Asie, 2002, no. 13, p. 311-360. halshs-03134299

\section{HAL Id: halshs-03134299 \\ https://shs.hal.science/halshs-03134299}

Submitted on 8 Feb 2021

HAL is a multi-disciplinary open access archive for the deposit and dissemination of scientific research documents, whether they are published or not. The documents may come from teaching and research institutions in France or abroad, or from public or private research centers.
L'archive ouverte pluridisciplinaire HAL, est destinée au dépôt et à la diffusion de documents scientifiques de niveau recherche, publiés ou non, émanant des établissements d'enseignement et de recherche français ou étrangers, des laboratoires publics ou privés. 


\section{La belle dame sans merci : les fantômes médiévaux à l'âge} moderne

François Lachaud

\section{Citer ce document / Cite this document :}

Lachaud François. La belle dame sans merci : les fantômes médiévaux à l'âge moderne. In: Cahiers d'Extrême-Asie, vol. 13, 2002. Moines, rois et marginaux. Études sur le bouddhisme médiéval japonais / Buddhist Priests, Kings and Marginals Studies on Medieval Japanese Buddhism pp. 311-360;

doi : https://doi.org/10.3406/asie.2002.1186

https://www.persee.fr/doc/asie_0766-1177_2002_num_13_1_1186

Fichier pdf généré le 06/02/2019 


\begin{abstract}
Dreams and Ghosts is the title of a book published in 1897 by Andrew Lang. Andrew Lang's title provides in itself an ideal summary of this article, the first one in a series devoted to the theme of necromancy in pre-modern and modern Japanese letters. This essay is an enquiry into the genealogy of the fantastic tale (gensō bungaku) in the modern era in Japan and an examination of the strong connections it established with traditional religion and the classics. In order to be read meaningfully, modern Japanese tales of the fantastic call for a closer examination of their classical forebears. They also require to be read in the light of various religious discourses born in the modern era, especially Buddhism. Eventually, they need to be confronted to their coeval Western counterparts in order to grasp both the differences in their treatment of the supernatural and the similarities in the motifs they commonly use.

The following pages deal with two illustrious writers Kōda Rohan (1867-1947) and Izumi Kyōka (18731939) who were the most famous heralds of resistance to modernity among the literati. Their best fictions belong to the genre (in fact, Kyōka 's entire career was devoted to the exploration of this Twilight Zone of Japanese imagination). Rather than giving a general survey of their works belonging to this precise category, the article is an examination of the use they made of the notion of dreams and ghosts, as they inherited it from the medieval corpus of the nō plays. The structure of the mugen nō (nō of illusions and dreams) they transposed into their fictional works is also closely connected to the Buddhist notions of redemption, of the after life and of gender.

The introduction deals with the general situation of Buddhism in modern Japanese letters and with the functions of the religious past in Rohan and Kyōka 's tales. The first part deals with the origins and the definition of the word mugen nō from Zeami's time to its revival in the Taishō era (1912-1926). The three other parts of the article are devoted to representative fictions of Rohan and Kyōka read in association with Buddhist motifs and the world of the nō plays. Many recurrent images run through texts like Taidokuro (Facing the Skull) (1890), Kōya Hijiri (The Holy Man of Mount Kōya) (1900) and Shunchū (One Day in Spring) (1906). In this article, we have dealt mainly with the oneiric structure of these texts and with the motif of the femme fatale around which the various tales develop. These two themes - one is structural (narrative patterns) and one belongs to the history of representations (ghosts), allow us to read these texts in close connection to the various classical sources meaningfully used by their authors to give birth to their fictional worlds. The form of the dream-play revived in the modern era, equally shows the possibility of transforming the writing of fiction into a necromantic rite of placation. In using Buddhist notions of the afterlife and of desire through the prismatic lens of the nō plays, these texts vindicate the classical notion of literature as a form of sacred conversation between the living and the dead.
\end{abstract}




\title{
LA BELLE DAME SANS MERCI : LES FANTÔMES MÉDIÉVAUX À L'ÂGE MODERNE
}

\author{
François LaChaUd
}

\begin{abstract}
Dreams and Ghosts is the title of a book published in 1897 by Andrew Lang. Andrew Lang's title provides in itself an ideal summary of this article, the first one in a series devoted to the theme of necromancy in pre-modern and modern Japanese letters. This essay is an enquiry into the genealogy of the fantastic tale (gensō bungaku 幻想文學) in the modern era in Japan and an examination of the strong connections it established with traditional religion and the classics. In order to be read meaningfully, modern Japanese tales of the fantastic call for a closer examination of their classical forebears. They also require to be read in the light of various religious discourses born in the modern era, especially Buddhism. Eventually, they need to be confronted to their coeval Western counterparts in order to grasp both the differences in their treatment of the supernatural and the similarities in the motifs they commonly use.

The following pages deal with two illustrious writers Köda Rohan 伴 (1867-1947) and Izumi Kyōka 泉鏡花 (1873-1939) who were the most famous heralds of resistance to modernity among the literati. Their best fictions belong to the genre (in fact, Kyöka's entire career was devoted to the exploration of this Twilight Zone of Japanese imagination). Rather than giving a general survey of their works belonging to this precise category, the article is an examination of the use they made of the notion of dreams and ghosts, as they inherited it from the medieval corpus of the nō plays. The structure of the mugen nō (nō of illusions and dreams) they transposed into their fictional works is also closely connected to the Buddhist notions of redemption, of the after life and of gender.

The introduction deals with the general situation of Buddhism in modern Japanese letters and with the functions of the religious past in Rohan and Kyōka's tales. The first part deals with the origins and the definition of the word mugen no from Zeami's time to its revival in the Taisho era (19121926). The three other parts of the article are devoted to representative fictions of Rohan and Kyōka read in association with Buddhist motifs and the world of the nō plays. Many recurrent images run through texts like Taidokuro 期鳞 (Facing the Skull) (1890), Kōya Hijiri 高野聖 (The Holy Man of Mount Kōya) (1900) and Shunchū 春昼 (One Day in Spring) (1906). In this article, we have dealt mainly with the oneiric structure of these texts and with the motif of the femme fatale around which the various tales develop. These two themes - one is structural (narrative patterns) and one belongs to the history of representations (ghosts), allow us to read these texts in close connection to the various classical sources meaningfully used by their authors to give birth to their fictional worlds. The form of the dreamplay revived in the modern era, equally shows the possibility of transforming
\end{abstract}


the writing of fiction into a necromantic rite of placation. In using Buddhist notions of the afterlife and of desire through the prismatic lens of the nō plays, these texts vindicate the classical notion of literature as a form of sacred conversation between the living and the dead.

In memoriam Jean-Jacques Origas,

La fermme fatale n'est pas du tout, comme on serait tenté de le croire, une création du romantisme. Sans parler de la belle Hélène dont l'orgueil de femme fatale fut vraiment comblé, chaque siècle a eu les siennes dont l'histoire a gardé le souvenir. La Bible elle-même en connait un certain nombre et non des moindres. En aucun cas, il ne faut les confondre avec les grandes courtisanes et les plus célèbres favorites. Ninon de Lenclos, pas plus que la Pompadour, n'ont mérité le titre. La femme fatale est toujours dans les meubles de famille, telle Cléopâtre en son palais, ou Marguerite de Bourgogne en sa Tour de Nesle. Réplique féminine de dom Juan, elle est moins attachée au bénéfice matériel et au plaisir sensuel qu'elle retire de son prestige, qu'à certaines satisfactions d'orgueil et de cruauté. Elle est à l'aise dans les grandes catastrophes et y montre une parfaite sérénité. Toutefois, elle ne recherche pas les aventures comme un dom Juan de Marana. On ne la voit pas courir la ville et la campagne pour briguer les hommages des hommes par des brimades provocantes et des discours habiles. Elle attend ses victimes à domicile. Son mystéricux pouvoir de séduction n'est pas seulement dû au vertige du sexappeal, mais encore et surtout à un satanisme de bonne étoffe.

Marcel Aymé, « La Femme Fatale », Paris Magazine, décembre 1933.

\section{I- Liminaire : spectres du bouddhisme}

Les fantômes, les créatures surnaturelles et fantastiques, sont imperméables au passage du temps. De la mort, ils n'ont plus aucune crainte et, par bonheur, ils sont, pour le lecteur ou pour celui qui sait se mettre à l'écoute du concert de leurs voix étranges, une source de compréhension du passé, soustraite aux « mensonges du réalisme » et aux prétentions positivistes de l'historien (nous parlons de l'époque révolue où il existait encore des historiens positivistes). La philosophie de leurs formes symboliques, pour parler comme Ernst Cassirer, ${ }^{1}$ l'examen de leur survivance (Nachleben) déclassée dans le monde moderne, pour

1 Voir, inter alia, "Der Begriff der symbolischen Form im Aufbau des Geisteswissenschaften », Vorträge der Bibliotek Warburg, 1921-1922, Leipzig-Berlin: Teubner, p. 11-39 et, surtout, pour la relation au langage, La Philosophie des formes symboliques 1 . Le langage, Paris: Les Éditions de Minuit, 1972 (première édition allemande 1923). Les êtres surnaturels seront envisagés ici, à travers les pages des livres et par leurs représentations figurales, comme une "collection de problèmes" (Sammlung von Problemen). 
reprendre l'articulation essentielle de la pensée critique selon Aby Warburg demeurent, dans leur cas, encore à faire. ${ }^{2}$

La modernité ne leur fut pas toujours bienveillante, tant s'en faut. Mais, dans sa volonté, pas toujours aussi ferme qu'il plairait à certains esprits de le penser, d'éradiquer ou de canaliser l'irrationnel, ils ont joué un rôle important de mise en lumière des zones restées obscures du monde et, également, en un mouvement pendulaire, d'obscurcissement des catégories nettes que l'on voulait imposer alors. De même, le fantastique a toujours eu, au Japon comme ailleurs, un lien privilégié avec le passé. Il est avant tout un inventaire, une relecture de celui-ci, mieux : un dialogue constant avec lui. Il fut aussi une critique constante de la modernité et de la culture dominante. ${ }^{3}$

Ajoutons que « Beautés et bizarreries», pour reprendre le nom de l'anthologie des écrits de Mario Praz publiée chez Mondadori en 2002, ont souvent fait, pour le bonheur de certains lecteurs, bon ménage. Pour ceux qui se risquent de l'autre côté des miroirs-sorcières de ces œuvres étranges, ils y peuvent lire les survivances d'un imaginaire classique réactualisé sans cesse par les divers avatars qu'il assume au cours des siècles, véritable fil d'Ariane conduisant au cœur de la tradition littéraire. ${ }^{4}$ Le versant obscur de l'écriture, forme absolue de nécromancie, comme Proust le montrait avec maestria dans le Temps retrouvé, ${ }^{5}$ ne cesse, à la manière d'une hantise, de refaire surface. Les pages qui suivent, en se mettant dans la foulée du nécromancien de la Via Giulia, se veulent une relecture d'un thème ou plutôt de quelques motifs, resurgissant dans la littérature fantastique moderne chez deux de ses tenants les plus originaux : Izumi Kyōka 泉鏡花 (1873-1939) et Kōda Rohan 幸田露伴 (1867-1947).

Le Japon, depuis les pages hantées du Kwaidan de Lafcadio Hearn (1904), apparut à l'horizon de certaines consciences littéraires occidentales - André

2 Une référence importante pour cet essai est le livre de Georges DIDI-HUBERMAN, L'Image survivante, Paris: Les Éditions de Minuit, 2002. Georges Didi-Huberman nous a par ailleurs donné de précieux conseils de méthode et d'investigation sur les traitements des fantômes et de leur représentation lors de son séjour à Kyōto en 2001, qu'il en soit ici remercié.

3 Voir Susan NAPIER, The Fantastic in Modern Fapanese Literature, Londres et New York: 1996, notamment p. 8 et suivantes. Susan Napier poursuit sa relecture du passé et de ses mythes dans son dernier ouvrage consacré aux dessins animés japonais. La communauté imaginaire que permet le recours au fantastique trouve dans ce genre une nouvelle fontaine de jouvence. Voir Gendai nibon no anime 現代日本のアニメ (Dessins animés japonais d'ajourd'hui), Tōkyō: Chūōkōronsha, coll. «Chūkō sōsho », 2002, notamment p. 37-69.

4 Les analyses sur les relations avec la part inquiétante du passé et sur le retour des formes antiques sont esquissées dans deux ouvrages dont la confrontation offre de véritables perspectives nouvelles pour l'histoire culturelle : Jacques LE RIDER, Freud, de l'Acropole au Sinaï. Le retour à l'Antique des Modernes viennois, Paris: Presses Universitaires de France, coll. « Perspectives germaniques », 2002 et Gerald FIGAL, Civilization and Monsters. Spirits of Modernity in Meiji fapan, Durham et Londres: Duke, 1999.

5 Sur ce point, voir l'article de Malcom BowIE, « The Miracle of Miracles », The Times Literary Supplement, 26 juillet 2002, p. 3-4. 
Pieyre de Mandiargues le perçut avec sa coutumière acuité - comme un territoire fertile pour le fantastique. Les noces de sang d'Éros et de Thanatos qu'il convoquait dans son dernier récit, Tout disparaîtra (1987), placé sous la protection des deux astres noirs que furent André Breton et Mishima Yukio 三 島由紀夫, sont un appel à cette redécouverte. La Sainte Trinité trônant au panthéon personnel de l'auteur - trinité que Breton vénérait lui-même, ainsi qu'il l'expose dans Arcane 17 enté d'ajours (1944) - Amour, Langage, Liberté, pourrait constituer l'une des clefs pour comprendre la fascination exercée par Kyōka et Rohan jusqu'à aujourd'hui.

Les monstres et autres fantômes ont souvent été étudiés pour eux-mêmes par les ethnographes et les folkloristes et, en relation avec les formes du sacré, par les historiens des religions. ${ }^{6}$ Le concept d'étrange, ce n'est pas un hasard, est au centre du texte de Rudolph Otto, ${ }^{7}$ Das Heilige, publié en 1917. Parti des idées sur le sublime, tels qu'elles apparaissent chez Emmanuel Kant et Edmund Burke, Otto décrit l'expérience du sacré comme une rencontre avec le radicalement Autre, le mysterium tremendum. Cette rencontre trouve l'une de ses formes les plus intenses dans la rencontre avec le monstrueux (das Ungebeure) et avec "l'inquiétante étrangeté »(das Unbeimlich). Cet éclairage sur le monstre qu'Otto développe autour de la figure du Léviathan, est aussi l'une des clefs que les modernes ont voulu découvrir dans les phénomènes surnaturels tels qu'ils figurent dans les textes littéraires et dans ceux relevant, proprement dit, de la religion. Le sentiment du monstrueux ainsi valorisé reprend la thèse burkéenne du sublime fondé sur la terreur. ${ }^{8}$ Celle-ci fut à l'origine de plusieurs des textes canoniques du fantastique occidental à la fin du siècle : Doctor Fekyll and Mister Hyde de Robert Louis Stevenson (1886), The Picture of Dorian Gray (1890) d'Oscar Wilde et Dracula (1897) de Bram Stoker. L'obsession de ces textes, aujourd'hui classiques, pour les problèmes posés par le féminin, la lignée et l'héritage traditionnel ne sont pas sans relation avec les textes japonais envisagés ici. Ceux-ci d'ailleurs ne se peuvent concevoir hors de toute relation avec leurs homologues d'Occident. Au vrai, les dissidents des lettres modernes au Japon se sont nourris des enjeux philosophiques et culturels de leur temps, qu'ils ont éclairé du « feu follet de l'imagination », pour reprendre l'expression de Walter de la Mare.'

6 Voir l'ouvrage, très riche, de Timothy K. BEAL, Religion and its Monsters, New York et Londres: Routledge, 2002.

7 Pour le legs de Rudolph Otto chez les spécialistes du fantastique en littérature, se reporter à S.L VARNADOO, Haunted Presence: The Numinous in Gotbic Fiction, Tuscaloosa: University of Alabama Press, 1987 et, pour une relecturc critique, à Noël CARROLL, The Pbilosopby of Horror or Paradoxes of the Heart, New York et Londres: Routledge, 1990.

8 Voir Edmund BURKE, A Philosophical Enquiry into the Sublime and Beautiful and Other Pre-Revolutionary Writings, Harmondsworth: Penguin Books, coll. « Penguin Classics », 1998, p. 86 et Peter FRANCE : «Lumières, politesse et énergie », dans Histoire de la rbétorique dans l'Europe Moderne, éd. sous la dir. de Marc FuMAROLI, Paris: Presses Universitaires de France, 1999, p. 983-985.

9 Desert Islands, Londres, Faber and Faber, 1930, p. i. « And as soon as the first step is made in venturing a little further afield, a bounteous, an illimitable prospect beckons 
Dans cet article, nous voulons proposer une lecture de quelques textes importants de Kyōka et de Rohan à la lumière du bouddhisme et de sa représentation dans les classiques, essentiellement les textes des nō (jp. yōkyoku 謡曲). Cette démarche devrait ouvrir à une relecture de l'héritage religieux et littéraire classique dans les textes relevant du fantastique à l'ère Meiji.

Le bouddhisme, on le sait, fut souvent laissé à l'écart par l'idéologie officielle de Meiji. Celle-ci, dans sa relation avec lui, pourrait presque se définir par deux expressions : l'une désigne la décision de séparer le « shintō » du bouddhisme (jp. shinbutsu bunri 神佛分離) et la seconde le mouvement subséquent de destruction des temples et de retour forcé à la vie laïque des moines (jp. baibutsu kishaku 度佛毁釋). La redécouverte et le développement du christianisme aidant, le bouddhisme fut condamné à n'être plus qu'un héritage du passé, féodal, irrationnel et conservateur. ${ }^{10}$ La littérature, dans ses grands mouvements, ne fit pas exception. Pour beaucoup de spécialistes, conscients de l'héritage des lettres pré-modernes et classiques, la littérature moderne ne naît qu'avec l'influence de l'Occident et la vision critique des lettres traditionnelles apparue dans son sillage. Les lettrés traitant du bouddhisme dans leurs œuvres se devaient soit de cantonner le rôle de celui-ci à un élément de décor, pour faire couleur locale, si l'on ose dire, puis, idéalement, en proposer une vision critique d'ordinaire négative, soit de reprendre la tradition bouddhique et se placer sous son égide pour composer leurs œuvres (une autre catégorie à distinguer de cette dernière serait la littérature confessionnelle et hagiographique qui, à petit bruit, a continué à prospérer jusqu'à aujourd'hui). Cette dernière catégorie est de loin la moins fournie. C'est en partie, et à un degré supérieur d'intelligence, le cas des textes étudiés ici."

Pour la première catégorie, celle du rationalisme qui devait engendrer le naturalisme un peu étroit du courant principal, sa vision du bouddhisme se résume assez bien dans un article écrit par l'un des grands opposants de Kyōka, Hasegawa Tenkei 長谷川天渓 (1876-1940) intitulé « Genmetsu jidai no geijutsu » 幻堿時代の藝術 (Les arts à l'âge du désanchantement), paru en 1906 dans le magazine Taiyo 太陽 $^{12}$ :

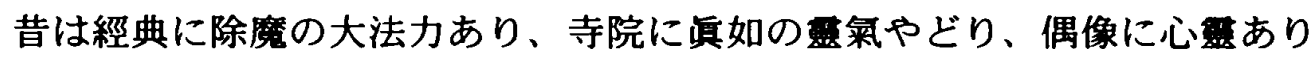

the explorer on, even though, as in this case, he may have nothing but the candle of curiosity and the will-o'-the wisp of enquiring ignorance to lead him on his way. "

${ }^{10}$ Sur les discours sur la religion à l'ère Meiji, voir l'excellent ouvrage d'IsOMAE Jun.ichi 純一, Kindai nibon no shūkyō genzetsu to sono keifu 日本近代宗教言説とその系 譄 (Les discours sur la religion dans le Japon moderne et leur généalogie), Tōkyō: Iwanami shoten, 2003.

"Sur le bouddhisme et la littérature de Meiji, se reporter à l'article de KENRI Bunshū 見理文周：《Kindai nihon no bungaku to bukkyō »近代日本の文と佛教 (La littérature du Japon moderne et le bouddhisme), dans Iwanami kōza Nibon bungaku to bukkyō 岩波䛍座日本文舉と佛教, Tōkyō: Iwanami shoten, 1995, vol. 10, p. 29-54.

12 Taiyo, comme on dit aujourd'hui, était une revue généraliste. Publiée à partir de janvier 1895 et jusqu'en février 1928, elle paraissait chez Hakubunkan. La politique, la société et les arts y tenaient la place la plus importante. 
と信ぜられしかど、今は其の難有味を感ずる人無し。古人の紀行文を見るに、 何の神社とか、何宗の本山とかに至れば、必ず山川草木に神佛の威を認め、 風雨鳥敬に神の言葉、佛の説教あるを聞くなど〉録したれど、今人如何に信 心を起しても、其の俤を見ず、其の響を聞かず、耳目に触る〉は只伽藍のみ、 神殿のみ、風景のみ。げに宗教界に於ける総ての幻像はしびたるなり。 ${ }^{13}$

Autrefois, on croyait que dans les textes bouddhiques demeurait le pouvoir de la Loi capable d'éloigner les forces du mal ; on croyait que dans les temples et les monastères demeurait le souffle spirituel de l'ainsité ; on croyait que les idoles étaient habitées d'un esprit, mais aujourd'hui, personne n'éprouve plus leurs bienfaits. Lorsque l'on regarde les récits de voyage des gens d'autrefois, ceux-ci à propos d'un sanctuaire ou du monastère principal d'une école $y$ font mention de l'autorité des buddhas et des divinités locales - toujours reconnue dans les monts et les rivières, les plantes et les arbres ; et on y entend le langage des divinités et la prédication des buddhas dans les voix du vent, de la pluie et des oiseaux. Les gens d'aujourd'hui, quelque foi dont ils fassent preuve, n'ont plus ces visions ; ils n'entendent plus ces échos. Les bâtiments des monastères et des sanctuaires, le paysage sont les seules choses qui parviennent à leurs oreilles et à leurs yeux. Au vrai, toutes les chimères du monde religieux sont réduites à néant.

Il y a plus dans ce passage qu'un remake en sino-japonais de la mort de dieu et du crépuscule des idoles. Le bouddhisme, dans le flux de son époque, semble voué à disparaître - notons que ceci vaut aussi pour le "shintō ». Les textes classiques n'ont plus de pertinence dans leur souci de transmettre ces croyances. Ils sont des vestiges que l'on doit filtrer au tamis du rationalisme. La mort des dieux et le crépuscule des idoles - reconnus en tant que tels - devraient amener à la littérature une possibilité de se défaire de ce pesant héritage. Cette doxa eut une importance que l'on ne saurait sous-estimer.

Rohan et Kyōka se situent à l'opposé de ce type de vues. Loin d'évacuer ce legs spirituel, sans le resituer non plus dans la veine de l'hagiographie ou des études philologiques donnant naissance à la bouddhologie moderne, ils inscrivent comme une marque - celle-ci peut être la simple récitation des textes sacrés dans leurs fictions, le bouddhisme au cœur de leur travail d'écriture. Ils sont ainsi en harmonie avec la meilleure part de l'héritage classique. Rohan en a une connaissance savante. Il en fait, durant toute sa carrière l'ample démonstration. Un récit comme Füryūbutsu 風流佛 (Un Buddha de splendeur) (1889) repose pour sa capitulation sur les Dix Ainsités (j. jūnyoze 十如是), l'une des catégories centrales de l'exégèse du Sütra du Lotus. Rohan a montré, certains lecteurs diraient étalé, partout dans son œuvre, sa connaissance en profondeur du bouddhisme. ${ }^{14}$ Kyōka, lui, lui a donné un rôle central dans

${ }^{13}$ Texte cité dans TAKAKUWA Noriko 高桑法子, Gensō no oiforī 幻想のオイフォリー (Euphorie du fantastique), Tōkyō: Ozawa shoten, 1997, p. 35.

${ }^{14} \mathrm{Un}$ autre exemple serait le texte intitulé Shin Urashima 新浦岛 (Le nouvel Urashima) paru entre janvier et mars 1895 dans Bungei kurabu 女檴俱樂部 (Le Club des 
plusieurs récits. Son bouddhisme a été celui des sans-grade, des superstitions dénoncées par les modernes. Les sūtras cités dans ses livres sont comme des formules magiques censées confirmer l'efficace des sortilèges du verbe.

Parmi les nombreux motifs bouddhiques présents dans les œuvres des deux écrivains et qui mériteraient dans chaque cas une lecture approfondie, deux d'entre eux retiendront notre attention ici : les pouvoirs quasi surnaturels de séduction de la femme, associée aux tentations de la chair et au monde de l'animalité, et celui de l'espace fantastique dans lequel se déroule l'action. Le premier motif est également celui qui définit les héros de deux textes : un homme égaré dans les montagnes qui résiste aux avances d'une mystérieuse femme et un moine encore jeune qui ne succombe pas à une autre femme. Communauté d'imaginaire, influence du premier texte sur les seconds, on pourrait proposer plusieurs hypothèses. Ici, nous essaierons de suivre l'élaboration de cette thématique au miroir de deux sources dissimulées par leurs auteurs : des pièces de $n \bar{o}$ qui abordent ce thème et lui donnent une profondeur dont leurs hypostases modernes se firent l'écho. En filigrane se lit également le second motif : celui de l'espace clos, retiré, d'où naît le fantastique, mais qui renvoie également à l'une des traditions les mieux attestées du genre, et ce depuis les récits des recueils d'anecdotes bouddhiques : le voyage de la capitale vers les provinces. ${ }^{15}$ Plus encore que tout autre motif, celui de la frontière entre la réalité et les illusions, entre les fantasmes et le vécu, entre le présent et la continuité des temps, s'impose par le rythme même qu'il donne à leurs phrases, par la manière dont il façonne l'économie des récits. Les textes envisagés ici sont comme des mondes en miniature dans lesquels il est possible de lire une autre forme de discours sur l'écriture et la modernité.

\section{II- Les territoires du songe}

La survivance du passé, celle qui constitue l'image-fantôme pour reprendre la dénomination de Georges Didi-Huberman, est l'une des caractéristiques du style de Kyōka et de Rohan dans un ordre similaire puis différent.

Les personnages des contes de fées, comme les fantômes, manifestent toujours une certaine propension à la mélancolie : ils n'arrivent jamais à mourir. Etrres de la survivance, ils errent comme des dybbouks, quelque

lettres). Rohan y réutilise un récit intitulé Shingon bimitsu Shōten sama 真言秘密聖天㥞 (Un secret de l'école ésotérique : Vināyaka). Ce récit parut initialement en dans la revue Sbincho byakusbu 新著百種 (Cent nouvelles œuvres) éditée chez Yoshioka shoten en 1891. Vināyaka, le dieu à tête d'éléphant, pourvoyeur (et destructeur) d'obstacles y tient un discours sur la magie noire au héros qui déploie toutes les connaissances de Rohan en la matière. Le même texte contient une analyse du darwinisme !

${ }^{15}$ Ce topos est aussi l'une des caractéristiques de la littérature fantastique européenne, de Mysteries of Udolpho d'Ann Radcliffe (1794) à Dracula. Voir les analyses de Victor SAGE dans Horror Fiction in the Protestant Tradition, Basingstoke: Macmillan, 1988 , p. 8 et suivantes. 
part entre un savoir immémorial des choses passées et une prophétie tragique des choses futures. ${ }^{16}$

Ce constat vaut aussi bien pour les héroïnes de Kyōka et Rohan que pour les textes qui les ont inspirés, ceux-ci tenant en quelque sorte le rôle d'une généalogie spectrale des fondements de leur imaginaire. La Vouivre de Marcel Aymé est aussi une incarnation de la survie mélancolique des êtres. Cette errance, cette survivance du passé, ce monde fantômal ont trouvé au Japon une incarnation particulière avec les pièces de $n \bar{o}$.

Le terme de mugen 夢幻 (ch. mengbuan), autre lecture japonaise yume maboroshi "illusions, rêveries, hallucinations, chimères ", au centre de cet article, pont flottant entre les œuvres de Kyōka, de Kōda Rohan et celui des textes médiévaux auxquelles elles se lient en de subtiles associations et arabesques, désigne à l'origine le rêve et les illusions. Très tôt, dans la pensée bouddhique, il fut associé à l'inconstance, l'impermanence de l'existence. C'est ainsi que Kūkai 空海 (774-835), le fondateur de l'ésotérisme japonais, l'emploie dans un texte du Shōryō shü 性臯集, le recueil de ses poésies et de ses textes littéraires : « La fragilité de mon corps est semblable à l'écume. Le caractère transitoire de mon existence est pareil aux illusions » 此身脆如泡沫。吾命假如夢 幻 (Kō.en bukkyō bō sbi ontoku byōbyaku 講演佛經報四恩徳表白 《Commentaire d'un sūtra en remerciement des vertus des Quatre Bienfaits »). ${ }^{17}$ Kūkai reprend l'une des images canoniques du Kongō bannyagyō 金剛般若經 (skt. Vajraccbedika prajñāpäramitā sütra), l'un des textes les plus lus dans les écoles chan/zen au Japon à la période médiévale. Ce sūtra est aussi l'un des textes bouddhiques qui servit à Zeami 世阿弥 pour l'élaboration de ses théories du $n \overline{0} .{ }^{18}$ Le texte chinois dit : « toutes les lois régissant les phénomènes (skt. samskrta dbarma) sont pareilles aux rêves, aux chimères, à l'écume et aux ombres » 一切有雼法如夢幻泡 影 ( $T$. VIII, 752 b). C'est en ce sens que l'écrivain moderne Natsume Sōseki 夏 目濑石 (1867-1916) utilise le terme au livre onzième de Wagabai wa neko de aru 我は猫である (Fe suis un chat) (paru en feuilleton entre 1905 et 1906):

心理に徹底しないものは、とかく眼前の現象世界に束縛せられて泡沫の 夢幻を永久の事實と認定したがるものだから、少し飛び離れた事を云ふと、 すぐて談にしてしまふ。19

Celui qui n'est pas frotté de psychologie est toujours lié et entravé

${ }^{16}$ L'Image survivante, op. cit., p. 512.

${ }^{17}$ Kōbō daishi zensh $\bar{u}$ 弘法大師全集 (CEuvres complètes de Kōbō daishi/Kūkai), Kōyasan: Mikkyō bunka kenkyūjo, 3 ćd. augmentéc, 1974, p. 506.

${ }^{18}$ Parmi les analyses récentes des influences du zen sur Zeami et le nō, voir GoMI Fumihiko 五味文彦, SANO Midori 佐野みどり, MATSUOKA Shinpei 松岡心平, Chüsei bunka no bi to chikara 中世文化の美と力 (Charmes et forces de la culture médiévale) Tōkyō: Chūōkōronsha, coll. " Nihon no chūsei », 2002, p. 288-298. Voir également le chapitre consacré à ce thème par UMEWAKA Naohiko 梅若直彦 dans Nögaku e no shōtai 能樂への招待 (Invitation au nô), Tōkyō: Iwanami shoten, coll. « Iwanami shinsho », 2003, p. 138-178.

${ }^{19}$ Sōseki zenshū 做石全集, Tōkyō: Iwanami shoten, 1993, vol. 1, p. 540. 
par le monde phénoménal qui se trouve sous ses yeux et il tend à prendre pour des réalités éternelles les rêves et illusions de bulles et d'écume ; c'est pourquoi, lorsque l'on dit quelque chose de singulier, il en fait sur le champ une plaisanterie.

Le terme de mugen est utilisé ainsi dans les nō. La fin (jp. kiri キリ) de Tenko 天鼓 (Tambour Céleste) en est un exemple parlant : « le son du tambour annonçant que la nuit va pâlir, de ses six coups se mêle aux voix du séjour des Six Destinées, réalité ou rêve, réalité ou rêve, tout n'était qu'illusions 》(夜も明け白む時の鼓、 數は六つの巷の罡に、又打ち奇りてうつつか夢か、また打ち寄りて現か夢か、幻と こそなりにけれ). ${ }^{20}$ La lecture du terme est ici yume maboroshi, séparés par un signe de ponctuation mais qui fusionnent ensemble pour insister sur le caractère transitoire et évanescent des choses. C'est le même sens que le mot revêt dans un autre $n \bar{o}, Y \bar{o} k i b i$ 楊貴妃 (Yang Guifei) : « toutes les choses ne sont que les jeux du rêve et de l'illusion, hélas ! elles ne sont que la danse d'un papillon 》 (何事も、夢 幻の戲㧈やあはれ胡蝶の舞ならむ). ${ }^{21}$ Le papillon de Zhuangzi se mêle ici au terme désignant le rêve et l'illusion issu du vocabulaire bouddhique mais familier dans sa lecture japonaise. Un seul exemple existe dans le corpus des $n \bar{o}$ avec la lecture mugen, mais dans l'expression mugen bōyō que l'on trouve dans l'exemple de Natsume Sōseki cité plus haut. Il s'agit de la pièce intitulée Kanebira 兼平 : « en vérité, au séjour des vies et des morts où sont les êtres vivants, on vient et l'on part en hâte. Que dire : l'ordre n'est point respecté entre vieillesse ou jeunesse ? tout n'est que rêves et illusions de bulles et d'écume ? 》(寅にや有篇生 死の巷、來つて去事速し、老少もつて前後不同、夢幻泡影何れならむ。

De ce constat d'impermanence des choses, de l'identité foncière entre le réel et le songe, une association se fit avec le terme japonais maboroshi 幺𠃌. Le terme, qui apparaît initialement dans les gloses japonaises de sūtras, signifie ce qui n'a pas d'existence et qui pourtant nous semble réel. Il rejoint le champ sémantique du caractère chinois buan (jp. gen) qui est celui de l'illusion, du mensonge, de l'irréel, de la vision ou de l'hallucination. Il désigne également la pratique de la magie, notamment de la nécromancie, la célèbre scène inaugurale étant le premier chapitre du Genji monogatari 源氏物語 où Genji souhaiterait, à l'exemple de l'empereur Xuanzong 玄宗, retrouver son aimée défunte par le truchement de quelque rite magique de nature à convoquer la morte.

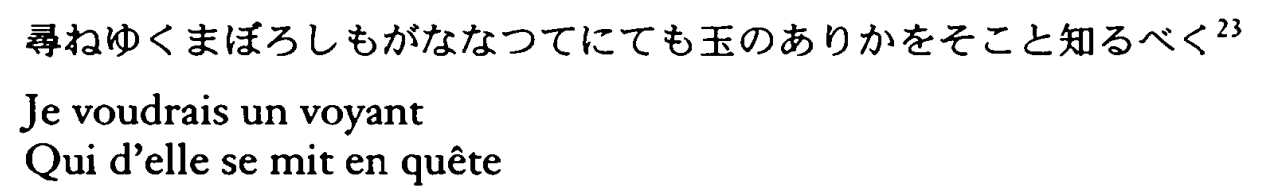

${ }^{20}$ Texte dans NiSHINO Haruo 西野春雄, Yōkyoku byakuban 譒曲百番 (Cent pièces de $n \vec{o})$, Tōkyō: Iwanami shoten, coll. "Shin Nihon koten bungaku taikei », 1998, p. 27.

${ }^{21}$ Id., p. 177.

${ }^{22}$ Id., p. 364 . Pour ces références lexicographiques nous renvoyons à l'ouvrage fondamental d'ŌTANI Tokuzō 大谷徳藏, Yōkyoku nibyaku gojūban sbū sakuin 譒曲二百五十 番集索引 (Index des deux cent cinquante pièces de nō), Tōkyō: Akao shōbundō, 1978.

${ }^{23}$ Texte dans Genji monogatari 源氏物語, Tōkyō: Iwanami shoten, coll. « Shin nihon koten bungaku taikei ", 1993-1996, vol. 1 p. 16-17. 
Même des propos rapportés

$\mathrm{Si}$ je pouvais seulement savoir

Le séjour de son âme

C'est aussi le titre du chapitre quarante-et-un du livre. Le nom du chapitre venant encore d'un waka traitant du même sujet :

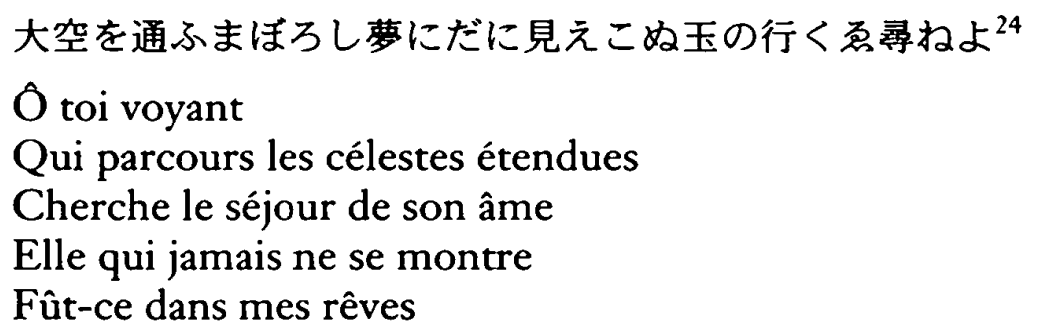

La pratique nécromantique est ici intimement associée aux rêves qui sont la porte d'accès vers l'au-delà. L'exercice littéraire devient, selon le modèle à jamais auguste du Genji monogatari, ce pont jeté vers l'autre monde que certains initiés peuvent parcourir à loisir.

Au vrai, c'est dans le $n \vec{o}$ que le terme de mugen a pris sa dimension esthétique qui devait façonner de manière durable les modes d'écriture du surnaturel au Japon. Les $n \bar{o}$ se divisent généralement en deux catégories : les « $n \bar{o}$ au présent » (jp. genzai $n \bar{o}$ 現在能), ${ }^{25}$ où le protagoniste est décrit comme une personne existant réellement, et les « $n \bar{o}$ hallucinatoires $/ n \bar{o}$ oniriques » (jp. mugen $n \bar{o}$ 夢幻 能) dans lesquels le temps et l'espace sont ceux du rêve du waki ワキ « témoin ; celui de côté (R. Sieffert) ». Lorsque ce rêve s'achève, alors tout n'est plus qu'illusion, fugaces images nées d'un songe et dont la trace rémanente change à jamais le protagoniste et le spectateur. Le terme de mugen nō est de naissance récente. Il fut conçu en 1926 par Sanari Kentarō 佐成謙太郎, l'éditeur du Yōkyoku taikan 誃曲大觀 entre 1930 et 1931 . Il s'agissait d'un cours à la radio intitulé «Kokumin rajio kōza 》 国民ラチオ講座 (Cours radiophonique populaire). ${ }^{26}$ Le mugen nō a pour personnage initial un voyageur qui se rend sur un lieu chargé d'histoire (jp. yukari no basbo 縁の場所). Là, il fait la rencontre d'une personne (le personnage principal, le shite シテ) qui lui apparaît sous les traits d'un humain ou d'un être de chair (jp. maejite 前ジテ) et lui relate des faits ayant trait au lieu où il se trouve puis, au terme de son récit, disparaît. Ceci constitue la première partie (jp. maeba 前場). Dans la seconde partie, le même personnage principal (jp. nochijite 後ジテ) ressurgit soit sous son apparence passée, soit sous la forme d'un être surnaturel. Il lui relate à nouveau les faits de son passé, à la première personne cette fois-ci, puis, il lui montre un signe extraordinaire (jp. kizui 奇端), danse et disparaît. La fin du rêve du waki replace l'histoire sous le signe de

${ }^{24}$ Id., vol. 5, p. 203-204

${ }^{25}$ Une excellente introduction figure dans Noël PERI, Cing nō. Drames lyriques japonais, Paris: Bossard, 1921, p. 62-66. Voir également Royall TYLER, Japanese Nö Dramas, Harmondsworth: Penguin Books, coll. « Penguin Classics », 1992, p. 1-21.

${ }^{26}$ Voir TASHIRO Keiichirō 田代慶一郎, Mugen nō 夢幻能, Tōkyō: Asahi shinbunsha, coll. « Asahi sensho », 1994, p. 6. 
l'illusion, elle opère aussi - et ce fut le génie de Zeami de lui donner forme, un effacement des frontières entre le rêve et la réalité. Le présent et le passé s'y fondent dans le secret d'un cœur dont les mouvements sont le lieu de l'action. L'action est centrée autour du seul personnage principal, qui revit le drame de son existence pour le protagoniste, pour les spectateurs et pour lui-même. La notion de catharsis, de purification, est au centre de cette conversation sacrée, de ce monologue sous deux aspects que constitue la pièce. Bien des variations et des enchaînements sont possibles sur ce canevas général. ${ }^{27}$

Il faut en outre ajouter que, si les grandes catégories des fantômes et spectres comprennent les âmes courroucées des morts de l'époque ancienne et de la littérature bouddhique médiévale (jp. onryō 怨露), le fait que celles-ci peuvent exercer leur influence même vivantes (jp. ikiryō 生露), et les spectres rendus populaires par la littérature d'Edo et le kabuki, Zeami semble être l'inventeur

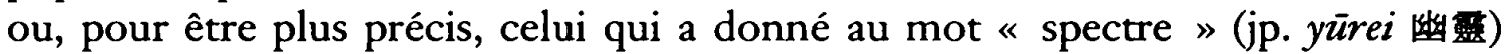
ses lettres de noblesse. Le premier sens du vocable désignait l'âme d'un mort. Celui qui vivait dans le monde obscur (jp. yümei kai 幽冥界) et qui se pouvait manifester aux vivants. Le terme était synonyme de shōryō 精垔 (le terme bouddhique désignant l'âme des défunts) et de shiryō 死 (l'âme des défunts pouvant causer des malédictions aux vivants). Ses équivalents étaient des mots comme mörei 亡露 et mōkon 亡魂 《 âmes défuntes ». Se fondant sur les croyances ayant trait à la malemort et au courroux de ses victimes sur les vivants, les spectres furent à l'origine des créatures suscitant l'effroi et la crainte. Ce n'est qu'à l'époque Edo que leur image se fixa peu à peu pour prendre celle de la personne émergeant d'un cercueil dont on ne distingue pas les traits et qui, généralement de sexe féminin, évolue sans jambes, les cheveux en bataille et les mains jointes devant elle, frappe les vivants d'horreur et en tire vengeance. Mais le mot yürei que Zeami contribua à acclimater en japonais désignait pour lui autre chose. Les pièces de mugen nō en sont la parfaite illustration : le spectre suscite la pitié plus que l'horreur (ce sentiment est absent dans la plupart des rôles de waki) et le théâtre devient le lieu d'une complexe liturgie de la parole et du corps visant à une réconciliation des deux mondes. ${ }^{28}$ Les spectres, comme le fantôme du père de Hamlet, se désignent comme tels :

あの松陰の苔の下、亡き跡韦はれ參らせつる、松風村雨是の幽踏是まで 來りたり。 29

Sous l'ombre mousseuse de ce pin, à nos dépouilles vous rendîtes

${ }^{27}$ Se reporter, pour une analyse du genre, à l'article de MURAKAMI Manabu 村上學, " Mugen nō », dans Iwanami kōza Nibon bungaku to bukkyō 岩波貄座日本文囷亡佛教, Tōkyō: Iwanami shoten, 1994, vol. 2, p. 181-201. Voir également les pages que consacre au nō Jacqueline PIGEOT, Michiyuki-bun. Poétique de l'itinéraire dans le fapon ancien, Paris: Maisonneuve et Larose, p. 305-312 et les commentaires de NisHINO Haruo, Yökyoku byakuban, op. cit., p. 751-754.

${ }^{28}$ Pour ce travail de la liturgie de la parole scénique et son rôle sur la généalogie des fantômes à la scène, voir Stephen GreenblatT, Hamlet in Purgatory, Princeton: Princeton University Press, 2001, notamment p. 205-257.

${ }^{29}$ Yökyoku byakuban, op. cit., p. 592. 
hommage. Nous voici, les fantômes de Matsukaze (Vent dans les Pins) et de Murasame (Pluie violente).

Par la suite, et quelles que fussent les influences de Zeami, la notion d'effroi se mêla de nouveau à l'image du fantôme et le monde spectral redevint habité par des êtres terrifiants, le plus souvent de sexe féminin. ${ }^{30}$

Dans cet article qui est consacré au fantastique de l'époque Meiji, il nous faut également rappeler à quel point le terme de mugen était ancré dans la modernité naissante. A partir des années vingt de l'ère Meiji, le mouvement de traduction des œuvres occidentales introduisit des représentants majeurs du courant «fantastique » : ce fut le cas d'Ernst Theodor Amadeus Hoffmann (1776-1822) et d'Edgar Allan Poe (1809-1949). A la fin de l'ère Meiji s'ajoutèrent des traductions de Maurice Maeterlinck (introduit par Mori Ōgai 森䣱外 (1862-1922) dans un essai écrit en 1902), d'Emile Verhaeren (18551916) et de Georges Rodenbach (1855-1898) (celui-ci est mentionné, par exemple, dans une lettre d'Akutagawa Ryūnosuke datée du 16 septembre 1910). Pour qualifier leurs livres, les termes en usage étaient les adjectifs « étrange » (jp. kaiki teki 怪奇的), « fantastique »(jp. gensō teki 幻想的) et, enfin, « fantasmatique » (jp. mugen teki 夢幻的, le japonais servant à traduire l'anglais fantasy et l'allemand Phantasie). Ces adjectifs servirent tour à tour à qualifier les films muets allemands se réclamant de la tradition romantique et fantastique : Der Student from Prag de Stellan Rye sur un scénario de Hans Eins Ewers avec Paul Wegener (1913, sortie japonaise en 1914), le Golem de Paul Wegener (la version de 1914, dans un décor modernc, cst projetée en 1916 au Japon ; la seconde version, dans un décor médiéval, fut tournée par Wegener en 1920), Das Kabinett des Doktor Caligari (1919, projeté au Japon en 1921). Enfin, alors que Sanari Kentarō créait un vocable appelé à une longue postérité, le terme de mugen avait déjà servi à désigner l'atmosphère de pièces comme celles d'August Strindberg (1849-1912) - particulièrement la pièce en trois actes Gengangere (Les Spectres) écrite en 1881 puis montée à Helsinki pour la première fois en 1883 - de Henrik Ibsen (1828-1906) et de Ferenc Molnar (1878-1952), surtout Illiom. On le voit à cette simple constatation dans le vocabulaire : la redécouverte du $n \bar{o}$ comme théâtre spectral se plaçait dans un contexte plus général. ${ }^{31}$

Les textes étudiés dans les trois sections de cet article sont à la fois une

${ }^{30}$ Ceci se produit déjà dans les pièces de nō ultérieures, notamment celles de Kanze Nobumitsu 䚋世信光世 (1435-1516). Voir l'article de TAKADA Mamoru 高田衛, « Onna wa

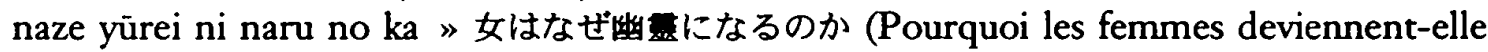
des spectres? ), dans Oizwa to Iemon お岩と伊右衛門 (Oiwa et Iemon), Tōkyō: Yōsensha,

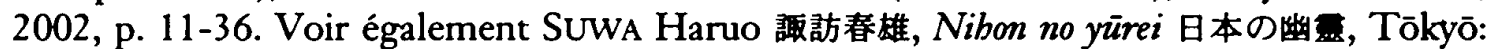
Iwanami shoten, coll. " Iwanami shinsho », 1988, p. 151-166. Sur la pertinence de l'étude des fantômes et sur la manière d'interpréter leur présence dans les textes littéraires et religieux de la Grèce antique, voir Sarah ILES JOHNSTON, Restless Dead. Encounters between the Living and the Dead in Ancient Greece, Berkeley et Los Angeles, 1999, p. 161-199.

${ }^{31}$ Voir l'étude de M. Cody PoulTon, Spirits of Another Sort. The Plays of Izumi Kyōka, Ann Arbor: Center for Japanese Studies, The University of Michigan, 2001, notamment p. 80-115. 
illustration de la présence du bouddhisme et de ses notions, populaires et savantes, chez deux des tenants de la contre-modernité à l'ère Meiji. Ils sont aussi articulés autour de la relecture des pièces de $n \bar{o}$ et de leur monde fantômal tel que nous l'avons défini ci-dessus. Bien sûr les dimensions de cet essai ne permettent pas d'ajouter d'autres exemples : ceux-ci feront idéalement l'objet d'un travail plus approfondi sur ces deux écrivains et le fantastique à l'époque de Meiji.

\section{III- Le crâne et la mendiante}

Le premier récit auquel cette section est consacrée est un texte de Kōda Rohan intitulé Engai en 縁外縁 (Un lien hors lien) paru dans la revue bimestrielle éditée par Hakubunkan 博文館, Nibon no bunka 日本之文華 (Belleslettres japonaises) en trois livraisons, correspondant aux trois premiers numéros en 1890 (début janvier, fin janvier et début février). A l'occasion de sa publication en volume chez Shun.yōdō 春陽堂 le 26 juin de la même année, dans un recueil intitulé Hasuesh $\bar{u}$ 葉末集 (Pointes de feuilles), Rohan donna un nouveau titre à son texte : Tai dokuro 對䯈鳞 (Face au crâne). Ce titre est celui sous lequel l'œuvre est d'ordinaire connue aujourd'hui. La version en volume est désormais le texte de référence. Rohan, pour des raisons personnelles devait le modifier à deux reprises : la première fois, lorsque l'œuvre reparut dans une série portant pour titre Roban sōsbo 露伴叢書 (CEuvres de Rohan) sous le titre Engai en en juin 1902, et la seconde fois en mai 1916 dans le volume Hakuro köro 白蕗紅落 (Rosée blanche, rosée rouge) publié chez Shun.yōdō, où le texte porte le second titre : Tai dokuro. Ce second titre devait l'emporter sur le premier, suite à la publication en 1926 d'une série de livres à un yen (jp. enpon 圆本) appelée Gendai Nibon bungaku zensh $\bar{u}$ 現代日本文学全集 (Collection de littérature contemporaine japonaise). Le texte disponible dans les œuvres complètes de l'auteur, Roban zensh $\bar{u}$ 露伴全集 - éditées chez Iwanami shoten 岩 波書店 à deux reprises en octobre 1941 et en mai 1978, est un texte qui collationne la version originale et les deux versions modifiées sans reposer sur des principes fermes d'établissement du texte. Pour la première publication en volume, il fut réuni avec un autre texte, également singulier, appelé Dokushushin 毒朱唇 (Rouges lèvres venimeuses). Ce dernier récit paru en janvier 1890 dans la revue Miyako no bana 都の花 (Fleurs de la capitale), éditée chez Kinkōdō 金港堂, puis en juin 1897 réuni en volume par l'éditeur Hakubunkan avec Tai dokuro sous le titre Högai shōsetsu Daishijin 方外小説大詩 人 (Récits de gens hors du monde. ${ }^{32}$ Le grand poète). Le premier des deux

${ }^{32}$ Le terme de bōgai (ch. fangwai) désigne ici les personnes qui ont quitté le monde. Ce mot qui pouvait désigner aussi bien les moines et les religieux bouddhistes et taoïstes, le plus souvent, mais aussi les médecins et les peintres est, à lui tout seul, une sorte de résumé des caractéristiques fictionnelles des personnages de Rohan. La définition du Xuedian 學典 est la suivante : "Le monde en dehors du monde vulgaire. L'usage ordinaire fait que le mot sert à désigner les personnes entrées dans la voie du bouddhisme et les religieux taoïstes 》(世俗之外。通常用來指佛門中人及道士。). Xuedian, Taipei : Sanmin shuju, 1992, p. 544. L'éditeur commit une bourde dans ses placards 
récits du volume, malgré le titre qui renvoie explicitement à l'image de la femme fatale, celle qui tient des propos venimeux et dont la bouche est le leurre qui peut faire plonger les hommes dans les gouffres du désir, est le récit d'une rencontre dans les montagnes entre une femme étrange retirée du monde sur le Mont Akagi 赤城山 pour se consacrer à sa dévotion au Buddha et un jeune héros qui lui apporte du sake pour la faire parler. Celle-ci se lance dans un long monologue pour expliquer que le buddha Śākyamuni fut le plus grand des poètes. Rohan se livre alors, il sera bientôt connu pour être coutumier du fait, à un morceau de bravoure mêlant textes canoniques et allusions profanes qui, sans préjuger de ses effets sur ses lecteurs, a le don d'endormir le héros ultimement chassé sous une cascade d'insultes. Mais, déjà dans ce texte, apparaissent plusieurs éléments essentiels à la fiction de Rohan : la femme fatale qui ne se laisse pas approcher, l'omniprésence du bouddhisme et de son legs lexical et philosophique dans l'écriture, les montagnes isolées demeures des spectres et des êtres surnaturels, enfin la fin dans laquelle on ignore le devenir de l'héroïne et où le héros se retrouve face à l'énigme de son expérience, celui qui a affronté un des mystères du monde, qui s'est tenu entre les vivants et les morts, à la fois medium et témoin comme dans les nō et qui devra rechercher d'autres occasions de vérifier sa virilité.

Tai dokuro permet d'analyser comment les notions bouddhiques et l'esthétique du mugen $n \bar{o}$ se fondent en un texte de fiction. Il s'agit du récit d'une « étrange aventure » faite par le narrateur, plaisamment appelé «Rohan ». ${ }^{33}$ Celui-ci, après quelques jours de convalescence aux eaux du lac du Chūzen-ji 中禅寺, décide de franchir à pied un col qui devrait l'amener de l'autre côté de la vallée. Action téméraire qui a pour but de montrer qu'il n'a

publicitaires et donna la graphie homophone 法外 signifiant « en dehors de la loi ; impuni par la justice ". Rohan faisait tout pour se soustraire à la censure : un comble !

${ }^{33}$ Pour l'essentiel, nous reprenons ici les éléments de notre article « Tai dokuro [Face au crâne] de Kōda Rohan : un miroir moderne de l'impermanence ", dans fapon Pluriel 2, Le Mas de Vert, Philippe Picquier, 1998, p. 165-174. Le nom de plume Rohan a pour origine ce récit. Au début du texte l'auteur/narrateur fait mention d'un baiku composé au cours d'un voyage solitaire d'un an dans les provinces du nord, " aux confins d'une lande, au cœur de la nuit et recru de fatigue »: "Très loin des villages/ J'irai dormir avec la rosée/ Oreiller d'herbes 》 (里遠しいざ露と侵ん草枕). “Depuis ce temps-là, mon corps est devenu le compagnon/l'ami de la rosée "; l'auteur en mêlant l'autobiographie et le récit fantastique, confond en un même nom son nom lettré et celui du narrateur : Rohan, " le compagnon de la rosée ». Il y a aussi dans le choix de ce pseudonyme, «celui qui dort avec la rosée ", un probable écho d'un passage du Gaoshi zhuan, (Biographies des hommes illustres) (高士伝), compilé par Huang Fumi (皇甫堣) sous les Jin (265-420). Il est dit dans le troisième volume, dans la vie de Jiaoguang : « Derrière lui, les feux sur la lande avaient brûlé sa hutte de roseaux, Guang dut dormir avec la rosée et affronter l'hiver. Il ôta d'abord ses vêtements, s'allongea et ne bougea plus. Les gens le tinrent pour mort. Lorsqu'ils le regardèrent, il était comme avant ». Ainsi, celui qui dort avec la rosée n'est pas le simple voyageur, mais, au contraire, l'homme illustre qui dépasse les contraintes de ce monde, peut en subir toutes les épreuves et s'en relever. Est-ce un hasard si le héros et l'auteur choisissent ce nom ? 
pas « froid aux yeux », et de contredire son caractère de « moine paresseux » qui ne supporte que " les austérités d'un moment " (jp. mikka bözu no ichiji shojiin 三日坊主の一時精進). ${ }^{34}$ Ses pérégrinations au cœur de la nature hostile, dans la montagne couverte de neige, se poursuivent par la découverte d'une demeure éclairée, à l'écart de tout, au milieu des monts. La personne qui habite en ces lieux s'avère être une femme à la voix grosse de séductions. Meurtri des douleurs de la marche, il lui demande alors l'hospitalité.

板戸引き開け身體を半分出す女、年は二十四五なるべし、後面に燈負ひ たれば後光さす天女の如く、其色の盿さ、其眼のぱっちりとしたる、其眉つ きの長く柔和なる、其口元の小さく締まりたる、其髪の今日洗いたる乎と覚 えて結もせず後ろに投げ掛て末の方を引裂き紙にて、一寸䋥めたる毛のふさ ふさとしてくねらざる、美しさ人にあらず。おのれ妖怪かと三足ほど退つて、 瞀へは女もつくつくと見て。 ${ }^{35}$

Tirant la porte de planche, et laissant apparaître à moitié son corps, une femme, âgée sans doute de vingt-quatre ou vingt-cinq ans, la lumière d'une lampe dans son dos, comme une divinité céleste entourée de son nimbe, la blancheur de son teint, ses yeux grand ouverts, la douceur de ses longs sourcils, sa bouche close menue, ses cheveux qui semblaient lavés d'aujourd'hui, dénoués, rejetés en arrière, leurs pointes pareilles à du papier déchiré, et qui, à peine rassemblés, paraissaient abondants et droits : non, sa beauté n'était pas celle d'un être humain. Je reculai de trois pas et, en l'examinant, je me demandais si j'avais à faire à un monstre ; la femme aussi me regardait avec intensité.

L'apparition de l'héroïne est décrite avec un choix de termes évoquant des caractéristiques surnaturelles qui vont bien au-delà de la simple beauté féminine (encore que Rohan ait tendance à peindre toutes ses héroïnes de ces traits exquis). Sa subtile beauté et ses charmes délicats la font ressembler aux êtres célestes de la destinée des dieux au sein des Six Voies (jp. rokudō 六道). Son nom est Otae お妙, le mot ayant en japonais des connotations à la fois d'étrangeté, d'habileté et de sublime. Il est très important, dans l'économie générale du récit, que la figure féminine apparaisse ainsi, revêtue de toutes ses grâces. La rencontre quasi surnaturelle en ces lieux est rendue avec beaucoup de justesse dans l'illustration qui accompagne la première livraison dans Nibon no bunka. La pose de la jeune femme évoque déjà par le pan de son vêtement qu'elle tient dans les mains un spectre ou un fantôme.

Plus tard, alors que la mystérieuse inconnue a insisté pour s'étendre à ses côtés, « Rohan » se sent envahi par la peur de succomber à la tentation charnelle, mais aussi par celle d'être la proie d'un être surnaturel qui hanterait

${ }^{34}$ Le tempérament ascétique et ses enjeux hérö̈ques, associés à un machisme omniprésent, sont l'une des caractéristiques de la plupart des personnages masculins de l'auteur.

${ }^{35}$ Texte dans Kōda Rohan shū 幸田露伴集, Tōkyō: Iwanami shoten, coll. «Shin Nihon koten bungaku taikei. Meiji hen », 2002, p. 257. 
les monts. On retrouve là plusieurs des thèmes traditionnels du fantastique au Japon. ${ }^{36}$ La femme s'approche de lui et elle se fait de plus en plus pressante, « belle et terrible à la fois » dans ses invitations à s'étendre aux côtés du héros, tout roidi par la séduisante menace. Elle lui prend la main. Rohan récite alors une formule taö̈ste pour ne pas tomber dans le piège charnel qui semble lui être tendu. Parmi les mots qu'il prononce figure une longue litanie orientée autour du thème du désir sexuel à l'origine de tous les vices et de la déchéance de l'homme :

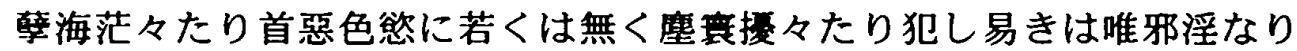
（略）芙蓉の白面は帯肉の娟髅に過ぎず、美跑紅妝、乃ち是殺人の利刀なり。

La mer des calamités est d'une incommensurable immensité, et de tous les maux il n'en est aucun semblable au désir sexuel ; ce monde de poussière et de souillure est en proie à la confusion, il n'est faute plus facile à commettre que l'impure concupiscence. [...] Le visage blanc comme un lotus n'est qu'un crâne ceinturé de chairs, les grâces et les fards ne sont que la lame acérée du meurtrier.

La femme est un être de mort, qui séduit l'homme et le mène sur les voies sans retour de la tentation et du désir. Le corps féminin, objet des convoitises du jeune héros, doit être tenu à distance et considéré, sinon pour ce qu'il est, du moins pour ce qu'il deviendra : une charogne puante, un cadavre disgracieux. Seul le cadavre féminin aperçu permet d'éloigner la meurtrière tentatrice. Le narrateur semble faire montre de courage et les vertus apotropaïques de la formule seraient presque sur le point de triompher, mais la femme se fait plus pressante :

我不動明王ほどの強き者にもあらねど、魔は却て梵天を攻めし摩酶修羅 の力を持てるかも知れず。毛を吹き㾋を求め草を打って蛇に會うは拙き上の 拙き事ぞかし。如何に答へん何と為さん、アア思ひ付たり、昔時は芭蕉も女 に袖を捉へられし事あるに彼黙然として動かず、女終に去らんとする時芭蕉 却つて女の袂を捉え、こちら向け我も淋しき秋の暮れと一句の引導渡せしよ し、小耳に挟んで聞覺へたり。我又良し良し芭蕉をまなんで黙然たらん計り と渐く一心を決し、胸中には九想の觀を凝らしながら乾坤を座断する勢い遈 しく兀然と座着すれば、女はもどかしがりて握りし手を尚強く握りしめ。サ ア露伴樣何考えて居らるる、此方へこちらへと引立る。 ${ }^{38}$

Je ne suis pas même un fort comme le Roi de Science magique Fudō, et l'être maléfique a peut-être la puissance de Makeishura qui assaillit Bonten. ${ }^{39}$ Chercher la petite bête pour qu'elle vous pique, battre les

${ }^{36}$ Voir, sur ce point, notre article "La Mort au neuf visages », dans Ebisu -Etudes Zaponaises, $\mathrm{n}^{\circ}$ 9, avril-juin 1995. Tōkyō: Maison Franco-Japonaise, p. 39-42.

${ }^{37}$ Köda Roban shü, op. cit., p. 264.

${ }^{38} I d$., p. 268. Remarquer la prescience de l'être surnaturel qui connaît le nom du héros, Rohan.

${ }^{39}$ Fudō-myōō (skt. Acala), "L'Immobile », est l'une des figures les plus populaires du panthéon bouddhique japonais. Il est représenté avec un visage courroucé, un corps généralement noir ou bleu noir. Il tient un glaive qui « subjugue les démons 
herbes pour y trouver un serpent : c'est là le comble de la maladresse. Que répondre ? Que faire ? Ah ! j'y suis : jadis Bashō, alors qu'une femme s'était accrochée à sa manche, garda le silence et ne bougea point ; par hasard il me souvient que, tandis qu'elle allait partir, c'est lui qui au contraire empoigna le bas de son kimono et laissa ce baiku comme un dernier verdict : « Tourne-toi ici/ Moi aussi je suis triste Crépuscule d'automne. " Je finis par prendre la résolution, à l'instar de Bashō de rester coi, je me concentrai sur la contemplation des Neuf Aspects, $m$ 'assis inébranlable avec une force et un pouvoir de trancher les erreurs de l'univers entier, et la femme semblant contrariée serra encore plus fort ma main et me tira vers elle en disant :

- À quoi pensez-vous, par ici, par ici.

Rohan, pour se déprendre des séductions du corps féminin et soumettre les forces du désir charnel, a recours à une technique de « contemplation de l'impur " (fujō-kan 不淨觀, asubba-bbāvanāa) résumée dans les « neuf aspects caractéristiques »( $k u s \bar{o}$ 九相) des stades successifs de la putréfaction, pour se défaire des leurres de la chair. Le vocabulaire choisi par Rohan n'est pas innocent, face à ce « démon féerique » qu'est la femme (jp. yōma 妖魔), il doit devenir un Jizō de pierre (jp. ishi fizō 石地蔵). Après qu'il ait réussi à terrasser les forces du désir et à maintenir une prudente distance, la seconde partie du texte consiste dans le récit de la femme qui l'a accueilli. Laissée seule au monde par les décès successifs de ses parents, la jeune fille bien née et « liseuse de récits ", s'était rcfuséc en mariage à un membre d'une grande famille, dont la fortune était assurée et qui, "l'année passée avait fait un séjour d'études en Allemagne et obtenu un diplôme ». En n'acceptant pas ce parti prometteur, l'héroïne condamne le jeune homme à mourir de langueur. Ce refus du mariage, elle se l'était imposé par fidélité au message que lui avait laissé sa mère sur son lit de mort et dont la révélation est rendue impossible par la venue du jour, mortelle à tous les spectres. Aux premières lueurs de l'aube, « Rohan » ne trouve plus à ses pieds qu'un crâne blanchi. Les galantes et romantiques confessions étaient celles d'un fantôme.

頓て又かすかに我を見て、あら毎モなき夜の短うて、可惜明放れなば假初 ながらの縁も是まで、君は片科川に浮く花、香は急流に伴って、十里を飛ぶ 遍やかに、我は其川の岸に立つ柳、影は水底に沈むで一歩も動るぎ難し、逢

passionnels » (B. Frank) et un lacet « instrument captateur ». Immobile sur son rocher, il figure la victoire sur les passions et les dérèglements des sens. Voir Bernard FRANK, Le Panthéon bouddhique au fapon - Les collections d'Emile Guimet, Paris, Réunion des Musées nationaux, 1991, p. 148-149. Voir également le livre de WATANABE Shōkō 渡辺照宏, Fudō-myōó 不動明王, Tōkyō: Asahi Shinbunsha, coll. « Asahi sensho », 1975, rééd. 1988, notamment p. 154-174. Makeishura est la transcription en lecture japonaise de Maheśvara, ou Iśvara (Jizaiten 自在天, Daijizaiten 大自在天), une divinité brahmanique, avatar de Siva, considérée souvent comme perverse dans les textes bouddhiques et que l'on figure avec trois yeux et huit bras, juchée sur un buffle blanc. Son combat avec Brahmā (Bonten) symbolise un affrontement avec les forces du Désir. 
ての喜び別 離のつらさ、戯けし橤の後朝ばかりにはあらずといふ時しもあ れ朝日紅々とさし登りて家も人も雲霧と消え、枯れ殘りたる去歳の荁薄の中

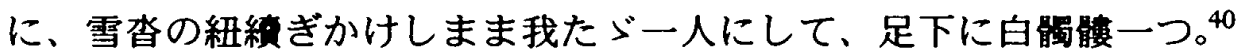

Puis à nouveau, me regardant imperceptiblement : «Hélas ! que les nuits sont courtes ! Il est dommage qu'une fois l'aube venue, le provisoire lien qui nous unissait s'achève; vous êtes une fleur à la dérive sur la rivière Katashina, votre parfum porté par le cours rapide des eaux traverse dix lieues en un instant, je suis le saule qui se tient sur ses rives, mon ombre s'abîme au fond des eaux et ne saurait s'ébranler d'un pas, les joies de la rencontre, la douleur des adieux : ce ne sont pas là simplement les séparations matinales qui suivent de futiles amours »... à l'instant même où elle prononça ces mots, les lumières du matin s'élevèrent dans un éclat rouge vif ; la maison et son habitante s'étaient dissipées comme nuages et brumes, et parmi les chaumes et les susuki ${ }^{41}$ flétris restés de l'année dernière, moi, tout seul avec mes raquettes à peine lacées et, à mes pieds, un crâne blanchi.

Le texte, sous le signe de l'impermanence, se condense en cette rencontre. L'illustration de Gōtō Yoshikage 後藤芳景, l'un des élèves de Kuniyoshi, résume à elle seule le point essentiel du récit. Arrivé à destination, lorsqu'il s'enquiert sur la possible présence de quelqu'un parmi ces montagnes, le patron de l'établissement de bain lui raconte alors qu'une mendiante folle et rongée par la lèpre rôdait voici quelques temps encore parmi les monts. Et le conte de s'achever par une atroce description du corps en lambeaux de la lépreuse, véritable « cadavre vivant ».

年は大凡二十七八、何處の者とも分からず、色目も見总ぬぼ゙污れ垢付 きたる檻樓を䋥る、破れ笠を負い掛け足には履物もなく竹の杖によわよわと すがり、談すさえ忌まはしきありさま、総身の色薄黑赤く處々に紫色がかり て怪しく光りあり、手足の指生姜の根のやうに届みて䇨もなきまで膨れ、殊 更左の足の指は僅に三本だけ残り其の一本の太さ常の人の二本ぶりありて其 続きむつくりと甲までふくだみ、右の足は拇指の失せし痕かすかに見え、右 の手の小指骨もなき如く柔らかさうに縮みながら水を持って氣味あしく大き なる垌のやうなり、左の手は指あらかた落ちて拳頭づんぐりと丸く、顔は 愈々恐ろしく銅の售子半ば熔ろけたるに似て、眉の毛尽く脱け額一体に凸く 張り出して処処凹みたる穴あり、其穴の所の色は褪めたる紫の上に清泥をう すくなすり付けたるよりまだまだ污く、黄色を帯びて鼠色に牡第の腐りて流 るる如き滕汁チクチクと兴れ、其滕汁の掩はれぬ所は赤子の舌の如き紅き肉 酷らしく露はれ莮柱缺け潰て其所に滕汁をしたたか湛え、上唇とろけ去りて 疎なる菌の黄ばみたると瘦せ白みたる菊眼と互いに照り合ひてすさまじく暴 露れ、口の右の方段々と燘れ流れたるより煩の半ばまで引きさけて奥歯人を 睨まゆる様に見え透き、髮の毛都て亡ければ朱塗りの資頭盧幾年か擦り摩で られて減りたる如く妙に光を放ち、今にも湞え破れんとする熟柿の如く齿や

${ }^{40}$ Köda Roban shū, op. cit., p. 284.

${ }^{41}$ Graminées dites « Plumeaux » en français. 
かなるそれさへ見るにいぶせきに，右の眼腐り捁たりて是にも丧汁尚乾かず、 右の眼の下瞼まくれて血の筋ありありと紅くも見ゆる程裹がへり、白眼黄色 く灭色に雯り、黑眼薄感色にどんよりとして眼球半ば飛出で、人をも神をも 仏をも逆目に睨む瞳子には急には動かさず、時々ホッとつく息に満腔の毒を 吐くかと覚えて犬も鳥も逃避ける、まして人間は人目見るより胸あしくなり、 其あしき臭ひを飯食ふ折りに思ひ出しては味噌汁甘く吸ひ得ず膿汁を思ひ出 しては珍重せし塩辛を捁てける、されば誰も彼も握り飯与ふるだけの慈悲を もせず其女の為すままに任せしに、彼呂律たしかならぬ歌のようなる者をあ はれに唸るを聞けば、世に捨てられて世を捨てて、叱叱と、覚束なく紐々と 繰り返して息だはしく、ハッタと空を睤みて竹杖ふりあげ、道傍の石とも云 はず樹とも云はず打ちたたきては狂ひまはり、狂ひ躍ては打ちたたき、䁲靑 の炎に心を焼き、狂ひ狂ひて行衛もしれず42

Elle devait avoir vingt-sept ou vingt-huit ans, on ne savait d'où elle venait, elle était couverte de haillons, criblés de crasse au point de n'en pouvoir distinguer la couleur ; un chapeau déchiré sur son dos, sans rien à ses pieds en guise de chaussures, elle s'appuyait toute faible sur une canne de bambou ; son apparence était funeste même à décrire, la teinte de son corps était d'un rouge noirâtre avec ici et là des traces de violet, il en émanait une étrange lumière ; ses doigts et ses orteils étaient recourbés comme des racines de gingembre et boursouflés au point d'en gommer les articulations, tout particulièrement les orteils du pied gauche qui n'étaient qu'au nombre de trois, mais chacun gros comme deux d'une personne normale, gonflés et redressés jusqu'au cou-de-pied ; sur le pied droit, on distinguait à peine la cicatrice correspondant à l'emplacement où avait dû se trouver le gros-orteil, le petit doigt de la main droite avait rétréci comme s'il n'avait plus d'os, il était plein d'eau et on eût dit un horrible et gros ver à soie, les doigts de la main gauche étaient pour la plupart tombés, seul restait le poing pansu et gonflé ; le visage était plus horrible encore, il ressemblait à un lion de cuivre à moitié fondu, les sourcils étaient tombés, le front semblait saillir comme une protubérance, à plusieurs endroits des trous y étaient creusés ; leur couleur était plus répugnante encore que si, sur le violet passé des chairs, on les avait frottés d'une mince couche de boue d'égout ; mêlée de jaune, une grise coulée de pus s'en déversait à jet continu comme des huîtres liquéfiées par la putréfaction ; aux endroits que le flot des sanies n'avait pas recouverts apparaissaient cruellement des chairs écarlates comme la langue d'un nourrisson, les arêtes du nez, pourries, avaient disparu, du pus s'échappait de la béance à grosses gouttes, la lèvre supérieure avait fondu, paraissait à la vue l'horrible éclat né du contraste entre les rares dents jaunies et les blanches gencives amaigries; du coin droit de la bouche lentement liquéfié par les ulcères jusqu'au milieu de la joue courait une déchirure par où l'on distinguait les molaires qui semblaient lancer de fulgurants

${ }^{42}$ Kōda Roban shü, op. cit., p. 285-286. 
regards ; la tête dépouillée de tous ses cheveux semblait celle d'un Dieu gardien des portes peint en cinabre que l'on aurait usé de caresses pendant de longues années, elle diffusait une étrange lumière, resplendissante comme un kaki bien mûr sur le point d'éclater ; sa vue saisissait déjà d'horreur, faut-il ajouter que son œil droit pourri était mort et que, là aussi, le pus n'était pas encore sec, la paupière inférieure de l'œil gauche était retroussée tant et si bien que l'on voyait nettement lc rouge vif du lacis des veines, le blanc de l'oeil avait jauni et était voilé d'une taie de cendres, l'iris noir s'était embruni, le globe oculaire était à moitié sorti, la pupille renversée qui jetait son courroux sur les hommes, les buddhas et les dieux ne pouvait plus se mouvoir avec rapidité ; aux souffles que de temps en temps elle exhalait, comme si elle vomissait tous les poisons de son corps, les chiens et les oiseaux s'enfuyaient. Pour les hommes c'était pire encore, la nausée les prenait à sa simple vue; quand je me rappelle l'horrible pestilence je ne puis plus boire avec plaisir ma soupe, le souvenir du pus m'a fait jeter les préparations d'entrailles de poissons que je gardais précieusement ; et personne n'ayant assez de compassion pour lui faire l'aumône, ne serait-ce que d'un peu de riz, tandis qu'elle était laissée à elle-même, on entendait la plainte poignante de sa voix comme un chant aux rimes incertaines, qui disait « abandonnée du monde et par celui-ci rejetée, j'enrage ", mêmes reproches ahanés d'une voix grêle et au souffle court ; conspuant tout d'un coup le vide elle brandissait sa canne de bambou et l'abattait sur les pierres du bord des chemins et sur les arbres, puis reprenait sa marche, égarée de folie ; secouée de démence encore et encore elle l'abattait, le cœur consumé par les feux de son ire, livrée entière à sa déraison, on ignore où elle s'en est allée.

La description du corps réel de l'héroïne est l'une des représentations les plus radicales de l'impureté et de l'horreur du corps de toute la littérature moderne (et sans doute classique) japonaise. Le corps féminin, cadavre vivant, est placé en antithèse et en antidote au premier corps glorieux de la déesse. Le récit de Rohan balance entre deux extrêmes du corps féminin, tantôt charmant tantôt horrible, tour à tour paré des appas de la jeunesse puis livré à la vieillesse et à la corruption. Le corps séduisant est celui d'une démone, le corps flétri est celui d'une morte-vivante. Le crâne y est à la fois figuration de l'impermanence et métaphore de l'humanité idéale que ne vient troubler ni les angoisses de l'audelà, ni les stériles enchantements des passions. A ce symbole apaisé du crâne s'oppose celui du corps en décomposition que le texte, en une hallucinante péroraison, donne à voir au lecteur. Le corps des femmes ne serait en fait qu'un cadavre exquis, prompt à charmer et à séduire, en même temps qu'à dévorer le mâle qui se serait égaré dans les labyrinthes du désir.

Le texte, ainsi qu'en témoignent les allusions savantes au bouddhisme - dont Rohan avait une profonde connaissance - et aux textes classiques mettant en scène le déclin et la mort d'Ono no Komachi 小野小町, n'est pas le simple produit des discussions sur l'évolution des espèces et sur l'infériorité de la 
femme à l'époque moderne. ${ }^{43}$ En ne voyant que ces éléments, aucune lecture de Tai dokuro ne saurait saisir les enjeux réels du texte. Ces enjeux sont les héritiers d'une culture bouddhiste pluriséculaire dans laquelle le corps des femmes est une incarnation des forces corruptrices du désir et en même temps une sorte de memento mori qui permet, si on sait le contempler, de mener l'ascète (ou le lecteur) vers le salut.

Pour comprendre la portée de ce texte et ce qu'il doit aussi bien à l'héritage classique qu'au bouddhisme, nous disposons d'une postface. Celleci vise plus à égarer son lecteur qu'à lui apporter des éclaircissements. Elle est aussi, comme beaucoup de textes du genre une volonté de placer le récit dans une filiation classique.

\section{対顝髉の後に書す}

荘子が記せし骨髏は太平楽をぬかせば、韓湘が歎ぜし骷髏は端唄に歌は れけるそれは可笑きに、小町のしゃれかうべは眼の療治を公家様に頼み天狗

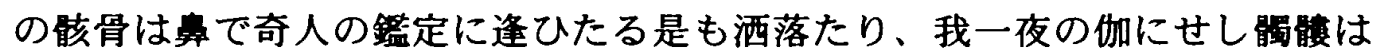
をかしからず酒落ず、無理におかしく酒落させて不幸者を相手に独り茶番、 とにもかくにも枯骨に向つて剣欛を篤する嘲りはまぬかれざるべし。44

S'il est amusant que le crâne mentionné par Zhuangzi dans ses écrits se répande sur la félicité suprême et que celui chanté par Han Xiang soit repris dans les airs populaires, il est élégant que celui de Komachi ait demandé à un noble de soigner ses yeux et que le crâne d'un démon ailé (jp. tengu) fût sans mot dire soumis au verdict d'un excentrique. I.e crâne qui me tint compagnie une nuit n'est ni drôle ni élégant; en vain je l'ai rendu tel, et de cet être malheureux j'ai fait une farce à mon seul usage. Au vrai, je ne saurais échapper au ridicule de celui qui a empoigné son sabre face à de vieux ossements.

Rohan situe l'œuvre dans la lignée littéraire d'histoires de crânes relevant des classiques et de la littérature populaire chinois et japonais. ${ }^{45}$ L'excentricité de Hiraga Gen.nai 平賀源内 (1728-1779) ou celle des exemples chinois donnés, celle, plus philosophique, du Zhuangzi 莊子 qui est une méditation sur la vanité, ${ }^{46}$ si elles se veulent un plaisant clin d'œil au lecteur, ne peuvent en réalité

${ }^{43}$ Voir, entre autres, le livre de KaWAMURA Kunimitsu 川村邦光, Sekushuariti no kindai セクシュアリティの近代 (L’âge moderne de la sexualité), Tōkyō: Kōdansha, coll. «Kōdansha sensho mechie », notamment p. 82-115.

${ }^{44}$ Id. p. 287.

${ }^{45}$ Voir l'article de KOMINE Kazuaki 小峰和明, « Mono iu dokuro »ものいう留 (Le crâne qui parle), dans Setsuwa no koe 説話の声 (La voix des anecdotes), T̄̋lvō: Shin.yōsha, 2000, p. 124-153 et surtout celui de TOCHIO Takeshi 枋尾武, «Dokuro no

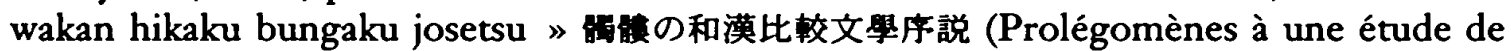
littérature comparée sur le motif du crâne en Chine et au Japon), dans Wakan bikaku bungaku 和漢比較文等, août 1998, p. 1-16.

${ }_{46}$ Voir HACHIYA Kunio 蜂屋邦夫, Sōshi : chōzoku no sakai e 莊子 : 超俗の境へ (Zbuangzi : vers l'au-delà du monde vulgaire), Tōkyō: Kōdansha, coll. « Kōdansha sensho mechie », 2002, p. 186-225. 
que masquer la véritable référence : les légendes ayant trait au crâne d'Ono no Komachi, ${ }^{47}$ telles qu'on les retrouve dans la littérature bouddhique et profane des recueils d'anecdotes (jp. setsuwa bungaku 説話文學).

La structure générale du texte peut se lire comme un apologue bouddhique : le récit de celui qui a vaincu les forces du désir et dont la récompense est de voir le devenir des corps de ceux qui se sont consumés aux feux de l'amour. La figure de la belle déchue et horrible, Ono no Komachi, en se situant dans la longue durée de l'histoire littéraire, offre à ce thème sa parfaite réalisation. Mais le cadre véritable qui permet à Rohan de mettre son récit en scène n'est autre que celui du mugen nō. Parmi toutes les références explicites, ce sont les seules que Rohan ne mentionne qu'à demi-mot : un $n \bar{o}$ Sotoba komachi 卒都婆小 町 (Komachi au stüpa). ${ }^{48}$

Le récit de Rohan suit la structure d'une pièce de mugen nō telle que nous l'avons évoquée ci-dessus. Le voyageur dans les montagnes, avec son obsession de la tentation charnelle y tient le rôle du moine, le waki, dans les pièces classiques. L'étrange et belle femme qu'il rencontre est le shite dans la première partie de la pièce. La fin de la nuit, l'entrée dans les songes et puis le crâne au matin marquent la fin des illusions et correspondent au moment du nakairi 中入 (la sortie temporaire du shite avant la seconde partie). Enfin, la dernière partie, au village d'Ogawa avec le récit du vieillard et sa description effroyable de la vieille folle errante révèle la véritable nature du shite, transformé cette fois-ci en créature extraordinaire, comme de juste. Cette association entre Tai dokuro et le $n \bar{o}$ est ancienne. ${ }^{49}$

Le récit n'est pas un récit de la capitale, ni des provinces, il est un récit de voyage. Si le personnage masculin, Rohan, est un représentant de la culture urbaine, les lieux choisis ne pouvaient être que retirés, comme les montagnes autour de Chūzen-ji. Le voyage du héros parti pour franchir le col de Konsei 魂 精岾 《Le Col des Âmes》 (graphie courante : 金精峠) est aussi, comme dans les $n \bar{o}$, un passage du monde de la culture à celui de la nature, du réel au surnaturel. La première partie, celle dans laquelle Rohan rencontre Otae et parle avec elle, constitue la première scène, (jp. maeba 前場) celle où il entend son histoire la seconde, enfin le crâne et la description de la vieille folle errante sont le lieu par excellence ou le nochijite fait son apparition. Le récit des attachements amoureux de l'héroïne, la rhétorique de l'obsession (jp. $m \bar{o} s h \bar{u}$ 妄執), centrale dans les $n \bar{o}$ mettant en scène spectres et autres êtres surnaturels, permet d'ailleurs de penser que, dans le récit de ses amours et du secret que lui transmet sa mère à propos du stigmate de la lèpre, elle est déjà l'être surnaturel

${ }^{47}$ Sur ce point, en dehors de notre thèse, La feune fille et la mort, Louvain: Peeters, (à paraître), voir les analyses de Terry KaWAshima, Writing Margins. The Textual Construction of Gender in Heian and Kamakura Japan, Cambridge et Londres: Harvard University Asia Center, 2001, p. 177-215.

${ }^{48}$ Noël PERI donne une présentation et une traduction excellentes de cette pièce dans Cinq nô, op. cit., p. 158-190.

${ }^{49}$ Voir SHIOTANI San 塩谷算, Kōda Rohan, Tōkyō: Chūōkōronsha, 1965-1968, vol. 1, p. 108-110. 
pour le repos duquel le héros doit prier. Le nō Komachi au stūpa permet de comprendre l'association centrale au récit de Rohan. Celui-ci est articulé autour de la rencontre entre un moine et une vieille femme horrible qui n'est autre qu'Ono no Komachi. Celle-ci est condamnée à l'errance, châtiment encouru pour avoir fait se languir d'amour et mourir son amant Fukakusa no shōshō 深 草の少将, « le capitaine Fukakusa ». Possédée par son spectre vengeur qui est la cause de sa folie, la pièce s'achève par sa récitation du nom du buddha Amida, le dernier geste que fait le héros après la découverte du crâne et l'espoir d'obtenir l'éveil. L'auteur utilise d'ailleurs dès le début une référence à une autre pièce de nō : Eguchi 江口. ${ }^{50}$ Dans cette pièce, une ancienne prostituée donne à un moine un sermon sur la soumission qu'il convient d'imposer au désir charnel, puis, dans une magnifique scène d'ascension, elle monte au ciel sous les traits du bodhisattva Fugen 普賢菩薩《Sage-universel 》 (skt. Samantabhadra). La sagesse toute bouddhique de la fin de cette pièce est celle que Kōda Rohan, met en œuvre par le truchement de son récit fantastique. La conversation entre les vivants et les morts, entre les classiques et ce récit moderne rédigé dans l'ancienne langue littéraire, entre les territoires de l'illusion et ceux, prosaïques, du réel est le véritable enjeu du texte. En mêlant, avec un superbe talent d'alchimiste, les deux tensions dramatiques, celle du désir et celle de son dépassement, Rohan construit un apologue. Derrière celuici, il retrouve les préoccupations de virilité de l'époque. Il faut résister à la chair. La femme dans les récits de Rohan est l'être qui met sur le chemin de la rédemption à condition de se défaire des leurres de la chair. Ceux-ci sont illustrés ici par les stigmates de la lèpre, qui œuvre à la manière d'un miroir.

La vision négative de la femme que Rohan reprend à la tradition bouddhique, est soumise, nous l'avons vu, au prisme de la structure des nō. La sexualité qui se manifeste par la séduction ne peut se donner carrière. Les fantômes du passé et les stigmates qu'ils impriment sur le monde réel autant que sur les rêves, empêchent la liaison charnelle d'aboutir. La femme idéale connaissait déjà une autre épiphanie chez Rohan, dans un autre récit tout frotté de bouddhisme et qui pourait constituer sa version japonaise du Portrait de l'artiste en jeune homme : Füryū butsu 風流佛 (Un Buddha de splendeur) paru en septembre 1889 dans Shincho byakushu 新著百種 (Cent nouvelles œuvres), revue littéraire éditée chez Yoshioka shoten. Le récit est, à sa manière, une autre lecture du monde moderne et de sa relation à l'art et au rêve. Le héros est un jeune sculpteur et imagier bouddhique dont le nom est Shu.un 殊運 qui, ne serait-ce que par son nom d'artiste, se veut un lointain héritier de l'illustre sculpteur Unkei 運慶 (mort en 1223). Pendant un voyage d'études il rencontre sur les routes de Kiso 木曾路 à Suhara 須原 une vendeuse de nommée Otatsu お 辰. Son père disparu et sa mère morte, Otatsu est élevée par son oncle qui est un voyou et un homme cruel. Shu.un sauve Otatsu des griffes de ce sinistre personnage et, après être tombé amoureux d'elle, il décide de convoler en de justes noces. Mais, la veille d'entrer dans l'état matrimonial, le père d'Otasu

so Texte dans Yökyoku byakuban, op. cit., p. 367-372. 
réapparaît ; il est désormais vicomte, et il emmène sa fille dans son auguste résidence de Tōkyō afin de la soigner. Shu.un, malade de langueur et affligé de mélancolie, comme Xuanzong pensant à Yang Guifei ou le père du Genji songeant à sa bien aimée, veut faire une image sculptée d'Otatsu qui en soit l'icône à jamais soustraite aux ravages du temps. Il songe d'abord à la revêtir des traits de Kannon, mais, suite à un rêve lui faisant penser qu'Otatsu s'est jouée de lui, il décide de la sculpter nue en taillant et élaguant les fleurs qui lui servaient de parure. Lorsque dans le journal il apprend les fiancailles d'Otatsu avec un aristocrate, il décide de détruire son œuvre, mais à ce moment là, la délicieuse créature scupltée dans le plus simple appareil, s'incarne et passe ses bras autour de son cou. En un baiser langoureux, Shu.un est emporté avec elle dans la nuée. Il y a là, derrière les discours sur l'art et la modernité qui ne sont pas ici notre thème principal, une autre figure d'ascension féminine.

今は恩愛切て塔迷はぬ初立歸る殊運に妨なす妖怪、いでいで佛師が腕の 讶、態も未練も段々に切塔てくれんと突立て、右の手高く振上げし釷には鐵 をも碎くべきが氣高く仁しき情溢るる許に湛ゆる姿さても水々として柔かそ うな裸身、斬らば熱血も迸りなんを、どうまあ邪険に鬼々しく刃の酷くあて らるべき、恨も憎みも火上の氷、思はず殊運は釷取落して、紮の叶はず思の 切れぬを流石男の男泣き、一㹂吞で身をもがき、其儘ドウと卧す途端、カタ リと何かの倒るる音して天より出しか地より湧きしか、玉の腕は温く我頸筋

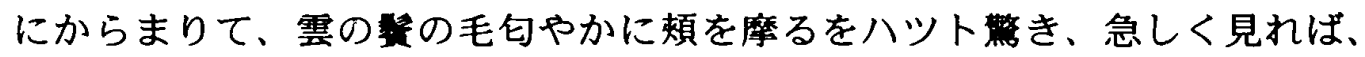
有し昔に其儘の。お辰かと殊運も抱しめて額に唇彫刻が動いたのやら、女が 來たのやら、問ば拙く語らば暒し、玄の又玄摩訶不思議。 ${ }^{51}$

En cet instant, hola! Shu.un se tint droit en face du monstre qui le tourmentait, lui qui avait tranché et rejeté amour filial et amour charnel et qui était revenu à son moi originel ignorant des égarements. Que la fraîcheur de son talent d'imagier bouddhique lui permette simplement de découper menu et l'amour et ses vestiges ! De sa main droite, la serpe qu'il avait brandie était de taille à réduire en miettes du fer, mais ce corps nu et souple si lumineux de vie, cette silhouette altière débordant de tendresse et de douceur, s'il les tranchait, leur sang enfiévré d'ardeur allait gicler ! Mais diable ! comment porter la lame avec cruauté et perversion, tel un démon, sur une telle œuvre ! Son ressentiment et sa haine étaient un feu pris dans les glaces; sans y pouvoir mais, Shu.un laissa tomber sa serpe, et, bien qu'il fût un homme, il ne put que pleurer devant son incapacité à trancher ce sentiment amoureux qui jamais ne serait payé de retour ; ravalant un cri et pris de convulsions, il s'effondra ainsi comme une masse. A cet instant, il se fit un bruit comme de quelque chose que l'on aurait renversé. Surgissaient-il du ciel ? jaillissaient-ils de la terre ? des bras immaculés entourèrent avec chaleur son cou, des tempes aux cheveux amples comme les nuées en de suaves effluves caressaient ses joues. Frappé de stupeur, il regarda brusquement alentour. Alors il la vit,

${ }^{s 1}$ Köda Roban shü, op. cit., p. 223-224. 
pareille aux jours d'autrefois. Otatsu ? Shu.un l'enlaça aussi, posant ses lèvres sur son front ; la statue s'était-elle mise à bouger? la femme étaitelle venue ? Poser des questions serait maladroit. Raconter viendrait trop tard. Mystère des mystères, comble de l'étrange!

Le dernier chapitre qui porte le titre bouddhique de «L'Aspect réel des entités » (jp. shobō jissō 諸法惯相) rappelle que l'amour entraîne toujours une réponse en retour et que Shu.un fut accueilli, comme les fidèles de l'amidisme, par la statue que lui-même avait de ses mains conçue. Et que l'un à coté de l'autre et les mains jointes ils sont montés aux cieux. La sexualité du héros, dans cette parabole bouddhique, est pour le moins sublimée. Seule sa sublimation dans le monde du rêve permet au récit de s'achever ainsi. C'est la réponse de Rohan aux discours sur les idoles et sur la mort des dieux. Il ne faut pas oublier non plus que cette nouvelle Kannon est une femme nue.

La misogynie bouddhique se mêle aux mondes parallèles du rêve pour créer un autre discours sur le corps. Mariée, domestiquée, confinée en son rôle de mère et de gestionnaire, la femme peut encore servir. ${ }^{52}$ Mais, en choisissant de lui donner ce rôle de porte vers l'Eveil et la rédemption, signe quasi-minéral comme le crâne de la fin de Tai dokuro, Rohan mène son lecteur à une lecture bouddhique du monde à travers le prisme de l'héritage littéraire classique et la forme des $n \bar{o}$.

思へば假の宿、思へば假の宿に、心留むなと人をだに諫めし我なり、是 まで成や歸るとて、則普賢、菩薩とあらはれ、舟は白象となりつつ、光と共 に白妙の、白雲にうち乘て、西の空に行給ふ、ありがたくぞ臨ゆる、ありが たくこそは䚓ゆれ。

Savoir que tout n'est que séjour provisoire, savoir que tout n'est que séjour provisoire, ainsi lui intimai-je de n'y point attacher son cœur. Voici l'instant venu où il me faut rentrer, alors elle apparut comme l'Être d'Eveil

${ }^{52}$ Le héros dans Isanatori いさなとり(Le pécheur de baleines) (1891-1892; publication en volume en 1892), rappelle d'abord que la femme est un être à fuir : "On ne saurait obtenir une paisible félicité qu'en ne s'approchant pas de la femme qui est la source de tous les maux. Ainsi fit-il. Les belles séduisantes inspirant la sensualité, il jugea leur compagnie sans profit comme un fer à cheval brisé, et vit s'accumuler les jours et les années en prenant pour ennemies jurées les créatures fardées de rouge et poudrées de blanc. 》(是も畢竟は諸惡の根源たる婦女に近づかねばこそ安樂を得るなれと、忿々啸女を忌

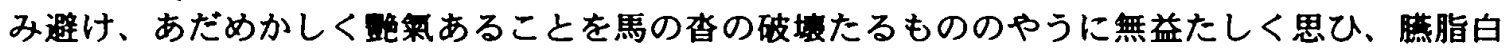
粉を仇㪣として日を送り年を重ねしに). Texte dans Kōda Rohan shū 幸田露伴集, Tōkyō: Kadokawa shoten, coll. «Nihon kindai bungaku taikei », 1974, p. 273-274. Mais à la fin, passé la quarantaine, il trouvera chaussure à son pied par l'entremise des deux domestiques qui le servent en guise de parents. Fi des baleines, il mènera désormais une vie conjugale conforme aux idéaux de son époque. Une femme point trop jolie mais capable, point trop érudite mais prête à rendre service. Sic transit gloria Veneris. Sa fille, sur le tard venue, s'appellera Osome お染 - celle qui teint, celle qui imprègne. La note bouddhique du prénom n'étant pas sans ironie.

${ }^{53}$ Eguchi, texte dans Yökyoku byakuban, op. cit., p. 372. 
Sage-universel, sa barque devint un éléphant blanc, avec la lumière, et enfourchant les sublimes nuées blanches, elle s'en alla à l'Occident du ciel. $\mathrm{O}$ songez à sa gratitude ! $\mathrm{O}$ oui songez bien à sa gratitude !

\section{IV- Ibi cubavit lamia ${ }^{54}$}

Le texte analysé dans cette section est l'œuvre la plus connue d'Izumi Kyōka : Kōya bijiri 高野聖 (Le saint homme du mont Kōya). Le texte parut initialement dans la revue Shin shōsetsu 新小説 (Nouvelles fictions), numéro daté du 25 février 1900. Il fut republié en volume en février 1908 avec un frontispice de Kaburagi Kiyokata 鏑木清 方 (1878-1972), aux éditions Sakura shobō 佐久良書房. Puis, dans les œuvres complètes éditées chez Shun.yōdō en septembre 1927 et, dans une recension plus complète, en 1940 chez Iwanami shoten. La première publication en revue et celle en volume constituent les textes de référence.

La figure de la femme fatale, relue à travers l'héritage bouddhique et le monde des pièces de $n \bar{o}$, est au centre de Köya

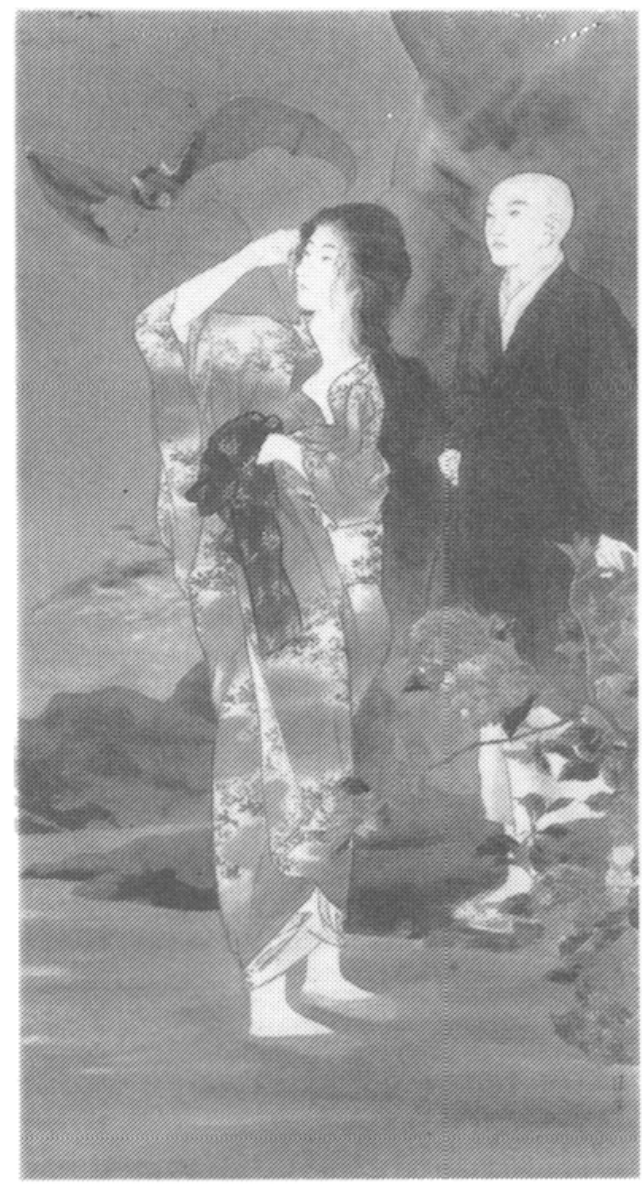

Kaburagi Kiyokata 木清方 (1878-1972)： Affiche illustrée pour Kōya hijiri (Kōyahijiri ekanban 高野聖䋨看板)，1904. Toyokawakaku

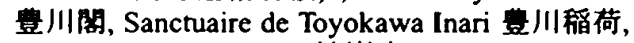
monastère du Myōganji 姑花寺. bijiri. ${ }^{55}$ Cette figure de la femme maudite,

${ }^{54}$ Texte latin de la Vulgate, Is. XxxIV, 14. Le français de Lemaître de Sacy donne : «C'est là que la sirène se retire, c'est où elle trouve son repos ». La Bible: Paris, Robert Laffont, coll. « Bouquins », 1990, p. 921.

"ss Sur le rapport entre les œuvres de Kyōka et les doctrines bouddhiques, voir l'article de TANIGAWA Kei.ichi 谷川惠一, «Izumi Kyōka. Tashō no kioku » 泉鏡花・他 生の記憶 (Izumi Kyōka. Souvenirs des vies antérieures), dans Iwanami kōza Nibon bungaku to bukkyō 岩波㩌座日本文學と佛教, Tōkyō: Iwanami shoten, 1995, vol. 10, p. 169191. Voir également notre article : « L'Ermite du mont Kōya, une lecture d'Izumi Kyōka », Ebisu. Etudes japonaises, 2, 1993, p. 67-81. Kyōka lui-même a distingué deux principes à l'ouvre dans son écriture. Le principe d'épouvante ou de terreur qu'il nomme « force démoniaque » (jp. kijin ryoku 鬼神力) et le principe compassionnel qu'il nomme « force de Guanyin/Kannon 》 (jp. Kannon ryoku 觀音力). Ses personnages féminins sont toujours un mélange des deux, préférant montrer un aspect à un type de personnages et un autre aspect à celui qui ne les sait pas comprendre ou qui les veut entraîner dans le monde de la carnalité. Voir le texte de Kyōka intitulé «Obake-zuki no iware shōshō to shojosaku »おばけずきにいはれ少々と處女作 (Quelques mots sur mon supposé goût pur les monstres et ma première œuvre) dans Kyōka zenshü, op. cit., vol. 28, p. 677-682. 
corruptrice parce qu'enracinant le mâle dans les méandres de la chair, doit beaucoup à l'héritage bouddhique. ${ }^{56} \mathrm{La}$ trame du récit est fondée sur le discours entre deux personnages. L'un, jeune, qui est le protagoniste du narrateur - la figure du waki, et le narrateur - le shite, un moine avancé en âge qui lui narre ses étranges aventures dans les monts de Hida 飛騨, où il fit la rencontre d'une femme ayant les pouvoirs de changer les hommes en bêtes. Le jeune homme est, malgré l'absence de renseignements précis à son endroit, un étudiant à la capitale, un homme du monde moderne, qui rentre dans sa famille à Wakasa. Après un chemin ardu dans les montagnes, entre les serpents et les sangsues qui sont des préfigurations des terribles pouvoirs de la femme des montagnes, et précédé par un vendeur de remèdes qui sera changé en bête, le héros rencontre la femme isolée au milieu des monts, comme dans le texte de Rohan. Celle-ci, fille d'un médecin malhonnête, est mariée à un idiot qui fut l'un de ses patients. Douée de pouvoirs magiques, elle a le pouvoir de transformer en animaux sauvages les hommes qui veulent avoir des rapports charnels avec elle.

Kyōka, pour situer son récit et inscrire son héroïne dans l'héritage classique, fait appel à la figure de la " Princesse des montagnes », yamabime 山姬. Celleci est bien connue dans la littérature ancienne. Elle apparaît ainsi dans un poème du Kokin waka shu $\bar{u}$ 古今和歌集 (n. 926):

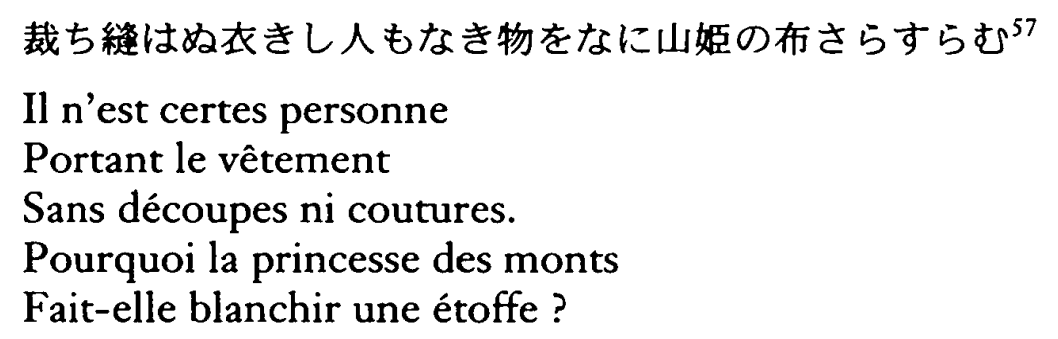

Ce waka de la poétesse Ise 伊勢 fut composé à Ryūmon 龍門 dans les monts de Yoshino 吉野, au pied d'une cascade. Le linge blanc est une métaphore, usuelle depuis l'époque du Man.yō sbū 萬葉集, se rapportant à une cascade. Le point important est ici que les monts de Yoshino sont considérés comme les demeures des immortels et qu'une divinité veille sur eux : la Princesse des monts. Le thème de la Princesse des monts était particulièrement d'actualité à l'époque de Meiji. Yanagita Kunio 柳田國男 lui accorde beaucoup d'importance dans plusieurs de ses travaux. Les montagnes ballucinées des légendes lui semblent non pas un

${ }^{56}$ Voir notamment l'ouvrage de TANAKA Takako 田中貫子, Akunyo ron 悪女論 (Théorie de la femme perverse), Tōkyō: Kinokuniya shoten, 1992. Les réflexions les plus subtiles sur cette figure se trouvent dans Camille PAGLiA, Sexual Personae, New Haven et Londres: Yale University Press, 1990, rééd. New York: Vintage Books, 1991. L'autre référence à ces visions de la femme fatale et enchanteresse demeure Mario PRAZ, La Carne, la Morte et il Diavolo nella Letteratura Romantica, 1930, rééd. de la cinquième édition revue, Rome: Sansoni, 1999.

57 Texte dans KoJIMA Noriyuki 小島割之 et ARAI Eizō 新井栄蔵, éd., Kokin waka shū 古 今和歌集, Tōkyō: Iwanami shoten, coll. "Shin Nihon koten bungaku taikei " (infra SNKBT), 1989, p. 278-279. 
microcosme dans lequel une spiritualité différente de celle du commun des Japonais aurait cours, mais, par la présence du surnaturel, des femmes-chamanes (jp. miko 巫女) qui y assurent depuis longtemps le rôle d'intercesseurs entre les vivants et les morts, elles sont au contraire un miroir de la religiosité du peuple ordinaire : cette religiosité que Yanagita et, à sa suite, les autres tenants du nativisme, se sont plus à redécouvrir ou, plus exactement, à inventer. ${ }^{58} \mathrm{Kyōka} \mathrm{se}$ situe lui dans la lignée des poèmes du Kokin waka shü comme en témoigne l'ouverture de Minodani罴谷 (Le Val du Manteau de Paille) (1895) :

見るから膚の粟立ツばかり涼しげなる瀑に面して、背を此方に向けたる は、惟ふに彼の怪しの姫なるべし。

羧谷の螢には主ありて、みだりに人の狩るをゆるし給はず。主といふは 美しき女神にておはすよし、母のつねに語り給ひぬ。占

Celle qui, me tournant le dos, faisait face à la cascade pleine de fraîcheur et dont la simple vue me donnait la chair de poule, devait être cette étrange princesse.

Il est un maître aux lucioles de Minodani qui ne tolère pas que les gens viennent les prendre sans motif. Ma mère me racontait toujours que ce maître était une belle déesse.

L'enchantement de la princesse des montagnes, le narrateur, comme Kyōka y succombe. Nombre de ses lecteurs aussi. Celle-ci est associée à un lieu maléfique (jp. masho 魔所), central, comme nous l'avons déjà vu pour Rohan, au déroulement de l'intrigue. La translation de la capitale à la nature sauvage étant aussi un mouvement du masculin vers le féminin, mais surtout le lieu de manifestation de la vraie nature des formes déclassées qui y survivent pour reprendre la terminologie warburgienne.

Dans cet imaginaire motivé par l'uchronie et la superposition des temporalités, les personnages masculins de Kyōka visitent les lieux saints ou maudits et, souvent s'en reviennent plus sages et plus tristes, moins capables d'appréhender le monde et plus aptes à en percevoir les subtilités, blessés de la modernité tel l'Ancient Mariner de Coleridge.

上の丘と下なる原とには、年長けてのち度々行けど、瀑の音のみ䦚きて 過ぎつ。われのみならず苃谷は恐しき魔所なりとて、其一叢の森のなかは差 親くものもあらざるよし。優しく、貴く美しき姫のおもかけ瞳につきて、今

${ }^{58}$ Voir, notamment son célèbre essai, Imo no chikara 妹の力 (Le pouvoir des femmes), dans Yanagita Kunio zenshū 柳田國男全集 (CEuvres complètes de Yanagida Kunio), Tōkyō: Chikuma shobō, 1989, vol. 11, p. 25 et suivantes. Sur ce point, voir également les analyses de KAWAMURA Kunimitsu 川村邦光 dans Miko no mizokugaku 巫女の民俗學 (Une étude ethnographique des chamanes), Tökyō: Seikyūsha, 1991, p. 1-58 et la somme de TAKAMATSU Keikichi, Miko to takaikan no minzokugaku teki kenkyū 巫女と他界観の民俗舉 的研究 (Étude ethnographique des chamanes et des conceptions de l'au-delà), Tōkyō: Hōsei daigaku shuppan kyoku, 1993, notamment p. 507-565.

${ }^{59}$ Kyōka zenshū 鏡花全集 (CEuvres complètes de Kyōka), Tōkyō: Iwanami shoten, 1973-1976, 30 vol., rééd. 1986-1989, vol. 2, p. 486. Toutes les citations de l'auteur, excepté celles tirées de Kōya bijiri, renvoient à cette édition. 
もなつかしき心地ぞする。物

Oui, après avoir grandi, je me rendis aux collines du haut et dans les landes d'en bas, mais je les traversais en n'entendant que la simple rumeur de la cascade. Il est vrai que je n'étais pas le seul à savoir que le Val de Minodani était un lieu terrible et maléfique : personne n'allait jamais jeter un regard dans cette forêt. L'image de la princesse, douce, vénérable et belle était gravée dans mes yeux ; maintenant encore j'en éprouve une indicible nostalgie.

Le vert paradis des amours enfantines, la possibilité d'entrevoir le monde des êtres surnaturels, de ces femmes splendides qui hantent et gardent les recès les plus obscurs de la nature et de son champ de forces : les héros des récits de Kyōka et de ses pièces ont ce don. Il les transfigure, il leur donne un regard nouveau, qui s'apparente à la fois au talent du poète pour réenchanter le monde et au malocchio qui jette sur lui la hotte de ses sorts.

Kyōka, pour élaborer ses figures de femmes fatales, notamment celle que l'on trouve dans Kōya Hijiri a eu recours aux classiques japonais, à la littérature populaire d'Edo, aux récits fantastiques comme l'Ugetsu monogatari 雨月物語 (Contes de la lune vague après la pluie) (1776) d'Ueda Akinari 上田秋成 (17341809), aux recueils d'anecdotes bouddhiques du moyen-âge et à leurs adaptations modernes. ${ }^{61}$ Dans Kōya hijiri il s'est appuyé notamment sur une pièce de nō nommée Yamanba. Il a, le fait est moins connu, conçu son histoire d'une femme changeant les hommes en bêtes à partir d'une adaptation de L'Ane d'or d'Apulée par Morita Shiken 森田思軒 (1861-1897) parue en japonais sous le titre de Konro dan 金敦譚 (Histoire de l'âne d'or), d'abord en feuilleton dans le Yübin bōchi shinbun 郵便報知新聞 (Les Nouvelles de la poste) entre le 18 janvier et le 2 février 1887, puis réunie en volume avec cinq autres textes dans Icbidoku ichikyō : sekai ichidai kibun 一誏一鷘一世界一大奇聞 (Une lecture, une merveille : Récits extraordinaires du monde entier) publié chez Mitani Heisuke 三谷平助 à Ōsaka en mai 1887 et réédité seul sous le titre Girisha ibun Konrodan 希脸異聞金 譃譚 (L'Âne d'Or : une histoire singulière de Grèce) à Tōkyō en juillet 1888 chez Murakami Shinsuke 村上兵助. ${ }^{62}$ Dans la version de Morita, Kyōka trouve trois thèmes qui lui servirent dans les œuvres mettant en scène une femme proche de la Princesse des monts : la métamorphose de la magicienne en hibou qui sera reprise dans Kömori monogatari 螎蝠物語 (L'histoire de la chauve souris) écrit en japonais classique en 1899, repris sous le titre Yuna no tamashii 湯女の魂 (L'âme de la femme des bains) en $1900,{ }^{63}$ et le rite conjuratoire servant à

${ }^{60} I d .$, p. 491.

${ }^{61}$ Sur le fantastique de l'époque Edo et sur sa relation avec Izumi Kyōka, voir notre compte rendu des ouvrages de Takada Mamoru, dans BEFEO 88, 2001, p. 430-438.

${ }^{62}$ Voir l'article de TEZUKA Masayuki 手塚昌行, Kōya hijiri seiritsu kō 『高野聖」成立考

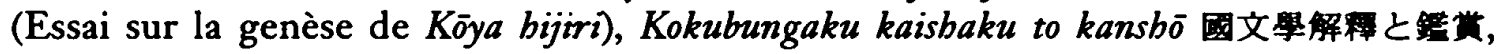
1959, vol. 1 et 1960 , vol. 8.

${ }^{63}$ Sur ce texte singulier de Kyōka, nous renvoyons à notre étude : « Mysteries of the Bat: Izumi Kyōka and the Fantastic Tale », Kyōto: Italian School of East Asian Studies Occasional Papers, 2003 (à paraître). 
transmuer les hommes en bêtes repris dans Hakukijo monogatari 白鬼女物語 (Histoire de la démone blanche) et, ensuite, sans donner de détails, dans Kōya bijiri. Enfin, la capacité à changer les hommes en bêtes... ${ }^{64}$

Derrière cette figure inquiétante de la Princesse des montagnes se trouve une définition que Kyōka connaissait, celle de Yamanba « La vieille des monts » autre créature surnaturelle ainsi définie dans une encyclopédie populaire de l'époque Edo (1603-1867), le Wakan sansai zue 和漢三才圖曾 (1712-1713) de Terashima Ryōan 寺島良安 :

野女やまうは・俗云山媼乎。蓋猩猩之類。本網野女日南國有之。状白色、

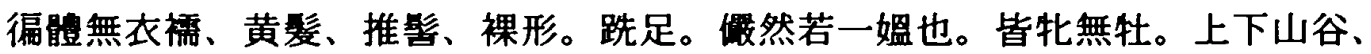
如飛㹮。自腰已下有皮、蓋膝群行、㒻夫。毎遇男子則必負去、求合。65

La femme des landes. Prononciation japonaise : yamauba. Désigne sans doute dans l'appellation populaire la vieillarde des montagnes, mais c'est en fait une variété d'orang-outang. Dans la Somme de la matière médicale (encyclopédie médicale de Li Shizhen, achevée en 1593 et imprimée en 1596), il est dit que les femmes des landes vivent dans les pays du Sud. ${ }^{66}$ Elles sont entièrement blanches d'apparence et ne portent pas de vêtements. Leurs cheveux sont jaunes et détachés. Elles sont nues et sans rien aux pieds. Elles ressemblent en tout point à une vieille femme. Il n'y a que des femelles et aucun mâle. Elles arpentent monts et vallées et sont semblables à des singes sauteurs. La partie inférieure de leur corps, à partir des hanches est recouverte de fourrure. Les genoux couverts, elles vont en groupe et cherchent un mâle. Si, par hasard, elles en rencontrent un, alors elles se mettent toujours à sa poursuite et cherchent à s'accoupler avec lui.

Ces sources qui, comme les textes de vulgarisation bouddhique sur les doctrines, formaient les références populaires de Kyōka, donnent une image très claire du personnage de la vieille des montagnes. Celle-ci présente plusieurs caractéristiques qui se mêlent aux enseignements misogynes du bouddhisme évoqués plus haut. Les principales sont l'animalité (mi-femme, mi-singe), la lamie ou la sirène de l'Antiquité reviennent à l'esprit, elles ont en outre un désir sexuel insatiable qui les conduit à vouloir s'accoupler à tout mâle rencontré. Ce monde de l'animalité figure aussi dans Yuna no tamashii où l'héroüne se transforme en chauve souris. Le texte basculant ainsi vers le vampirisme.

Au vrai, pour comprendre les enjeux du texte de Kyōka, il convient de relire avec soin le nō Yamanba. Il faut également garder à l'esprit que le monde du nō fut dès l'enfance un univers dans lequel Kyöka se sentit familier. Sa mère était la

${ }^{64}$ Sur la femme fatale chez Kyōka voir l'article de SUDA Chisato 須田千里, « Kyōka ni okeru ma teki bijo no keisei to tenkai »鏡花における「魔」的美女の形成と展開 (Formation et développement de la figure de la femme maléfique chez Kyōka), dans MrTA Hideaki 三田英彬 éd., Izumi Kyōka 泉鏡花, Tōkyō: Kokusho kankōkai, 1996, p. 94-308.

${ }^{65}$ Wakan sansai zue, Tōkyō: Tōkyō bijutsu, 1970, vol. 1, p. 459 bas.

${ }^{66}$ Ce terme vague est glosé par plusieurs naturalistes de l'époque Edo comme désignant le Japon. 
fille de Nakata Toyoki, un joueur de tambour de l'école Kadono. Le grandpère de Toyoki, Nakata Mantarō, fut lui aussi un acteur de nō qui joua sous le patronage du clan Maeda, les seigneurs du fief de Kaga, situé au sud de l'actuel département d'Ishikawa. Plusieurs de ses œuvres de jeunesse, ainsi que certains textes majeurs de la maturité, traitent directement du monde du $n \bar{o}$. Deux exemples sont Teriba kyoggen 照葉狂言 (1896) et Uta andon 歌行燈 (Lanterne du chant) (1910).

Le $n \bar{o}$ Yamanba, ${ }^{67}$ l'un des plus célèbres de Zeami, raconte le voyage d'une danseuse, partie d'Echizen 越前, passant par les provinces de Kaga et d'Ecchū 越 中 pour se rendre en pèlerinage au Zenkō-ji 善光寺. Le monastère fut - et demeure - l'un des principaux lieux de pèlerinage japonais et il a constitué l'un des principaux centres de l'amidisme populaire. La figure de la danseuse, dont le nom est Hyakuma Yamanba, son nom étant un doublet de la vieillarde des montagnes (noter également le jeu phonétique avec byakuma 百魔 - les cent démons, s'inspire d'une véritable danseuse de ce nom, mentionnée dans plusieurs textes médiévaux. Parvenue à la « Rivière de la frontière » (jp. Sakaigawa 境川), elle doit, pour parvenir au Zenkō-ji emprunter un chemin qui la conduit au cœur des montagnes, du monde de la culture au monde du surnaturel. Alors que sur les sentiers difficiles le jour se met à tomber avec une rapidité singulière, une femme vivant seule dans une demeure isolée parmi les monts fait son apparition et lui offre l'hospitalité. Mais, en échange de celle-ci, elle veut que la danseuse exécute pour elle le morceau dans lequelle elle brille et excelle : une danse (jp. kusemai 曲舞) à l'origine de sa renommée qui consiste, précisément, en une représentation de la vieillarde des montagnes. Après quelques hésitations, lorsque la danseuse s'exécute, l'habitante des montagnes révèle sa vraie nature : c'est elle la démone, la véritable vieille des montagnes. Elle confesse sa terrible destinée : après s'être abandonnée au désir sexuel, elle fut dévorée par un démon et, sous la terrible lumière de la lune, elle aussi se met à danser. Invisible fantôme, elle aide aujourd'hui encore les bûcherons à porter leurs lourds fardeaux et les tisserandes dans leur travail sur le métier. Mais, les gens la tiennent pour un démon, la mettent à l'écart et elle est condamnée, pour les siècles et les siècles à venir, à errer de montagne en montagne. Après avoir confessé son passé en paroles et par la danse, elle disparaît à l'horizon. La nature de la vieille des montagnes est déjà celle de l'héroïne de Kōya bijiri : être terrible qui peut faire montre de ses terribles pouvoirs, elle peut être aussi salvatrice, comme le moine qu'elle guérira dans les eaux enchantées de la rivière où, une fois l'ordalie de la tentation charnelle subie avec succès, elle sera pour lui une déesse guérisseuse. ${ }^{68}$ L'illustration de Kajita Hanko 捤田半古 lors de la parution dans Shin shōsetsu donne à cette scène qui est l'une des plus sensuelles de la littérature japonaise moderne, une parfaite incarnation graphique.

${ }^{67}$ Texte dans Yökyoku byakuban, op. cit., p. 160-167.

${ }^{68}$ En cela, elle rejoint la nature de yamanba telle que la définit ORIKUCHI Shinobu dans un essai de 1928 consacré au personnage du vieillard sacré : «Okina no hassei 》爷 の搏生 (Naissance du vieillard sacré). Voir Kodai kenkyū 1 古代研究 I (Etudes sur l'époque ancienne), Tōkyō: Chūō kōronsha, coll. « Chūko classics », 2002, p. 344-346. 
Le texte se fonde sur trois figures féminines qui permettent de relire à sa lumière la figure de la princesse des monts et de la vieillarde des montagnes. Le maejite, femme merveilleuse et pleine de grâce de la première partie, le nochijite, démone terrible et inquiétante de la seconde et la danseuse (le tsure ツレ), qui erre parmi les monts et dont la quête trouve une forme d'achèvement avec celle qui en constitue la parfaite incarnation : yamanba, la vieille des montagnes. En fait, l'opposition entre ces figures féminines se fait par le truchement de l'espace géographique. A la femme de la capitale, qui est une incarnation de la beauté,mais aussi de l'errance, répond celle de la démone qui, sous ses deux aspects, est une créature des étendues sauvages. En fait, la danseuse voit dans la forme de l'être surnaturel sa propre nature d'artiste et de femme réalisée. Dans sa très grande subtilité qui est aussi celle de la danse, le texte instaure une série d'oppositions qui sont centrales dans le récit de Kyōka. L'espace montagnard et sauvage s'oppose à celui de la capitale, le monde démoniaque (soit, pour reprendre la terminologie médiévale japonaise le makai 魔界) s'oppose au monde profane (jp. zokukai 俗界), la nuit s'oppose au jour et la danseuse à la démone. Le personnage central de Kóya bijiri est une figuration de ces différents antagonismes. Le rôle du désir sexuel y est accenué avec le vendeur de médicaments, un double mauvais du moine qui se retrouve changé en bête.

Un passage de Köya hijiri permet de mieux comprendre ce subtil jeu d'interaction entre les mondes opposés dans l'espace de la fiction :

否、別のことぢやござんせぬが、私は癖として都の話しを聞くのが、病 でございます、ロに蓋をしておいでなさいましても無理やりに聞かうといた しますが、あなた忘れても其時聞かして下さいますな、可うござんすかい、 私は無理にお專ね申します、あなたは何うしてもお話しなさいませぬ、其を 是非にと申しても断つて仰有らないやうに屹と念を入れて固きますよ。69

Non, ce n'est pas grand chose de spécial. J'ai pour manie, maladive, de vouloir entendre des histoires de la capitale ; même si ta bouche est fermée par un couvercle, j'essaierai à toute force d'en entendre ; oublierais-tu mes paroles, que tu ne dois jamais me faire aucun récit de ce type. Je te le demanderai, mais tu ne dois sous aucun prétexte parler. Garde bien présent et gravé dans ton esprit que tu dois refuser et ne rien dire, même si j'insiste.

Comme la vieille des montagnes qui veut admirer la danse venue de la capitale, un interdit, semblable à ceux qui figurent dans les contes et les légendes, se trouve au cœur du récit. Les histoires de la capitale sont aussi celles du monde profane, celles de nature à mettre en avant les tentations de la chair et ainsi de faire encourir au narrateur le sort réservé aux amants de la magicienne. Le monde de la modernité, celui auquel l'héroïne appartenait à l'origine, celui qui a engendré son mari idiot, celui de son père médecin véreux, est aussi, comme

${ }^{69}$ Nous suivons la remarquable édition critique de TOGO Katsumi 東郷克美 dans Izumi Kyōka shū 泉鏡花集 (CEuvres d'Izumi Kyōka), Tōkyō: Iwanami shoten, coll. « Shin Nihon koten bungaku taikei. Meiji hen ", 2002, p. 348. 
le vendeur des médicaments et sa manie incurable de draguer et séduire, celui de la sexualité masculine régnant en maître. Ce sont les territoires du phallus qui, tels la carte d'état-major figurant au début du récit, marquent de leur empreinte, de leurs projections le monde. Alors, lorsqu'il est brandi, tel un attribut, lorsqu'il cherche à pénétrer les mystères du naturel féminin, il trouve son châtiment comme de juste. ${ }^{70}$

此の白癡殿の女房になつて世の中へは目もやらぬ 換にやあ、㜔様は如意 自在、男はより取つて、飽けば、息をかけて獣にするわ、殊に其の洪水以来、 山を穿つたこの流は天道様がお授けの、男を誘ふ怪しの水、生命を取られぬ ものはないのぢや。71

Devenue la femme de ce crétin, bien sûr elle ne se soucie plus du monde, mais la belle peut à sa guise et à volonté choisir un homme, et, lassée de lui, le transformer en bête ; c'est pire depuis l'inondation, ce courant qui a creusé la montagne est une eau étrange donnée par le ciel pour séduire les hommes. Personne ne peut garder la vie sauve.

Le châtiment de la modernité est donc d'être rendu au statut d'animal. L'intérêt et le charme, au sens le plus fort du récit de Kyōka, tiennent dans cette ambivalence du personnage féminin. La même que dans d'autres textes précurseurs abordant les même motifs : Minodani et Ryütan dan 龍潭譚 (Histoire du gouffre du dragon) (1896). Ces récits, pour ne mentionner que les principaux, sont bâtis sur une trame identique à celle développée à sa pleine maturité dans Kōya hijiri. Les héros jeunes et innocents ne peuvent accepter les enjeux de la sexualité : celle-ci, métaphore de la modernité phallique qui vise à faire porter sa marque sur l'infini des phénomènes, les conduirait à la bestialité, à être ces animaux qui viennent assaillir le moine dans la maison livrée à la nuit " profonde comme le fond de la vallée ». Pour se défaire de ses enchantements funestes, pour ne pas être condamné aux sorts des amants malheureux de cette Cléopâtre, il faut, comme dans les $n \bar{o}$, faire appel aux pouvoirs du langage à la langue sacrée des sütra qui, par sa simple incantation, libère des pouvoirs funestes : ceux de la modernité qui refuse les vertus du bouddhisme et loue le crépuscule des idoles, et ceux de la femme qui, selon les doctrines anciennes, incarne la chair corruptrice. L'alchimie produite par les textes des sūtras est, en quelque sorte, une des figures de l'écrivain selon Kyōka : celui dont le langage est à la fois une forme supérieure d'enchantement et de libération.

Même si le moine en disparaissant dans les nuées comme un immortel, dit ne prodiguer aucune leçon, l'apologue bouddhique qui constitue la trame de

${ }^{70}$ Voir l'article de David J. SKAL «The Fatal Image », dans son anthologie critique Vampires. Encounters With the Undead, New York, Black Dog and Leventhal, 2001, p. 223-257. Une analogie pourrait être établie avec Frankenstein de Mary Shelley (1818 et 1833). Dans ce texte classique les figures masculines à commencer par Victor Frankenstein veulent pénétrer les secrets de la nature : «I have described myself as always having being imbued with a fervent longing to penetrate the secrets of nature », Frankenstein, Harmondsworth: Penguin, coll. «Penguin Classics », 2003, p. 47.

${ }^{71}$ Izumi Kyōka shü, op. cit., p. 399. 
Kōya bijiri est, en fait, entièrement contenu dans le personnage féminin. Celuici fonctionne, comme beaucoup de textes médiévaux japonais sur une association entre deux pôles contraires : les passions - la femme est une tentatrice, ainsi lorsqu'elle essaie de séduire le moine au bord de la rivière - et l'Éveil - celui du moine qui sait lui résister, qui comprend sa vraie nature maléfique et, par la leçon qu'il donne au jeune homme dans l'auberge, sait la transmettre pour son édification. La capacité du moine à garder les défenses, à ne pas succomber à la tentation, mais aussi à faire preuve de compassion pour celle dont le sort est d'être pour toujours ? dans les montagnes en la compagnie de l'idiot et du vieil homme (figures héritées du passé religieux) est, in nuce, la morale du texte (jp. kyōkun 教訓). Le vieil homme vient lui rendre visite et lui sert de factotum pour les animaux-humains qu'elle peut vendre sur les marchés ; il donne au texte sa pleine dimension religieuse. Reste la nature de cette Circé des monts Hida :

天狗道にも三熱の苦瑙、髪が亂れ、色が荅ざめ、胸が瘦せて手足が細け れば、谷川を浴びると畄の通、其こそ水が垂るばかり、招けば活きた魚も來 る、睨めば美しい木の實も落つる、袖を殹せば雨も降るなり、眉を開けば風 も吹くぞよ。

然もうまれつきの色好み、殊に又若いのが好ぢやで、何か御坊にいうた であらうが、其を實とした處で、德て飽かれると尾が出來る、耳が動く、足 がのびる、忽ち形が變ずるばかりぢや。

いや、留て此の鲤を料理して、大胡坐で飲む時の魔神の姿を見せたいな。72

Même dans la voie des démons ailés, on est tourmenté des Trois Fièvres ; quand ses cheveux se trouvent en désordre, quand ses couleurs pâlissent, quand sa poitrine maigrit et que ses mains et ses jambes se font trop fines, il lui suffit de s'asperger des eaux du val et la voici comme avant, revêtue d'une aquatique fraîcheur. A son invitation les poissons vivants viennent, un regard hostile et les fruits tombent des arbres, une manche en abat-jour et la pluie se met à tomber, un froncement de sourcils et les vents soufflent!

Elle aime le plaisir de naissance, et tout spécialement les hommes jeunes, pardi ! A vous le bonze, je ne sais pas ce qu'elle a raconté, mais si vous l'aviez cru, quand - très vite - elle se serait lassée, une queue vous aurait poussé, vos oreilles se seraient mises à bouger, vos jambes se seraient allongées et, en un rien de temps, vous auriez changé de forme.

Oui, quand d'ici peu, elle va cuisiner cette carpe et se mettre à boire assise en tailleur, j'aimerai bien vous montrer son apparence d'être démoniaque!

Le vampire de la forêt : telle est donc cette figure de l'éternel féminin présentée ici. Comment ne pas songer à l'image du vampire, tel que Stoker la représente dans Dracula ? Capable de changer de forme, de maîtriser les éléments, de se nourrir de l'ardeur masculine - une autre lecture du thème de l'eau est celui du liquide séminal qui laisse les individus comme autant de cosses vides. Les sangsues

${ }^{72}$ Id. p. 399. 
dans la montagne en sont la métaphore qui court tout le long du texte. Kyōka mêle à son texte de subtiles allusions sexuelles : ainsi, le héros, lorsqu'il est au bord de la rivière en un état de ravissement et d'oubli de soi proche de l'orgasme, suggéré par l'immersion dans les replis suaves d'une fleur, semble devoir être absorbé dans l'univers liquide qui l'entoure. Le recours aux doctrines bouddhiques, l'utilisation délicate du nō Yamanba pour élaborer à la fois le personnage principal et la structure du récit, l'enracinement du texte dans la mémoire religieuse sont autant de manières de faire de ce texte un exemple de discours critique sur la modernité. Nul part ne pourrait-on trouver un démenti plus fort aux allégations de Hasegawa Tenkei mentionnées au début de cet article.

Le bouddhisme à l'horizon des textes de Rohan et Kyōka évoqués jusqu'ici et l'héritage littéraire classique des $n \bar{o}$, situés dans l'espace intercalaire, l'entredeux (jp. chükan 中間), trouve sa forme la plus démarquée du modèle original et en même temps la plus subtilement aboutie dans un autre récit qui fait l'objet de la dernière partie de cet essai.

\section{V-Genius loci : la fin des illusions?}

Li He 李賀 (791-817) demeure, par excellence, dans la poésie de la dynastie Tang une figure inclassable et admirée. Les travaux chinois, japonais et occidentaux sur lui, après une poignée de publications majeures semblaient marquer le pas. Réparation partielle fut faite en 1993 par Kurokawa Yōichi 黒川 洋 - et son anthologie, remarquable, de poèmes de $\mathrm{Li} \mathrm{He}$ en collection de poche et, surtout, en 2001 avec la publication d'une Élucidation de ses poèmes, sous la direction de Wang Xiaoqiang 王暁強. ${ }^{73}$ Allusif, précieux, audacieux dans ses images, obsédé par le monde des esprits et des morts : tant dans le choix de ses sujets que dans celui de son style, $\mathrm{Li} \mathrm{He}$ fut l'écrivain de la bantise.

\section{蘇少少墓}

幽蘭露。如啼眼。無物結同心。煙花不堪剪。草如茵。松如蓋。風爲裳。 水爲聥。油壁車。夕相待。冷翠燭。勞光彩。西陵下。風雨䀲。

La tombe de Su Xiaoxiao

Rosée sur les orchidées cachées, Comme des yeux noyés de larmes.

Nul serment d'amour noué,

Les fleurs de brume ne puis couper.

Les herbes comme coussins,

Les pins tels un dais.

Le vent est sa jupe,

L'eau sa ceinture de perles.

Dans sa voiture aux parois huilées,

${ }^{73}$ Voir Li He sbi jiemi 李贺詩解謎, Suinan: Shandong youyi chubanshe, 1998.

${ }^{74}$ Nous suivons ici, pour le dernier caractère du poème, la leçon de KUROKAWA Yōichi dans Riga sbisen 李贺詩選 (Choix de poèmes de Li He), Tōkyō: Iwanami shoten, coll. « Iwanami bunko », 1993, p. 29-33. 
Elle attend à la brune.

De froides chandelles d'émeraude, Epuisent leurs feux.

Sous le Mausolée de l'Ouest, Le vent et la pluie noires.

Le fantôme d'une courtisane qui, en vain, attend ses amants. Dans ce poème à la splendide mélodie (vers irréguliers, trois rimes), se succèdent les images d'une belle, qui, d'année en année, de siècle en siècle, se languit de ses galants et laisse entendre son chant, les soirs de vent et d'orage, sur sa tombe. L'image des feux follets, ${ }^{75}$ " froides chandelles d'émeraude ", est peut-être, avec celles des orchidées cachées, ${ }^{76}$ le meilleur symbole des belles dames sans merci étudiées dans cet article. Le poème n'est pas sans évoquer une autre figure spectrale, cette foisci, à travers la course des siècles, chez Walter de la Mare (1873-1956) :

The Ghost

'Who knocks?' 'I, who was beautiful,

Beyond all dreams to restore,

I, from the roots of the dark thorn am hither.

And knock on the door.'

'Who speaks?' 'I-once was my speech

Sweet as the bird's on the air,

When echo lurks by the waters to heed;

'Tis I speak thee fair.'

'Dark is the hour!' 'Ay, and cold.'

'Lone is my house.' 'Ah, but mine?'

'Sight, touch, lips, eyes yearned in vain.'

'Long dead these to thine...'

Silence. Still faint on the porch

Brake the flame of the stars.

In gloom groped a hope-wearied hand,

Over keys, bolts, and bars.

A face peered. All the grey night

In chaos of vacancy shone;

Nought but vast sorrow was there-

The sweet cheat gone. ${ }^{77}$

${ }^{75}$ Le commentaire de Wang Qi 王琦 dit, «Chandelles d'émeraude : désigne les feux follets. Ceux-ci ont un éclat mais point de flamme 》(翠娬. 鬼火也.有光而無䱮.). Voir $L i$ He shi jiemi, op. cit., p. 73.

${ }^{76}$ On note, dans le vocabulaire poétique classique, les termes de shuailan ${ }^{2}$ (jp. suiran) « mourantes orchidées 》 et de kulan 枯蕑 (jp. koran) 《 orchidées fanées 》. Li He shi jiemi, op. cit., p. 72.

${ }_{77}$ The Complete Poems of Walter de la Mare, Londres: Faber and Faber, 1969, p. 196197. Nous remercions les auditeurs de nos conférences à Kyōto et Cambridge pour leurs suggestions sur les relations et parallèles que nous avions établis entre de la Mare et 
Le monde des fantômes qui apparaissent à la faveur d'une nuit, symboles d'inquiétude et d'élégance, $\mathrm{Li} \mathrm{He}$, dont le poème cité plus haut fut adapté en japonais par Satō Haruo 佐藤春夫 (1892-1964), en fut l'incomparable chantre ; l'unicité de sa voix ayant laissé son indurée cicatrice sur la poésie chinoise et japonaise. Ce poète, Izumi Kyōka le lisait en composant la suite de l'un de ses récits les plus célèbres, Shunchu gokoku 春昼後刻 (Suite d'un Après-midi de printemps). Une maîtresse page de son Autocbronologie (jp. Fibitsu nenpu 自筆年 譜) nous entraîne, avec sa coutumière étrangeté, dans les méandres de son esprit. Hantise et fantômes se pressent dans un quotidien à la fois inquiétant et onirique, Kyōka part, une fois de plus, vers Die Andere Seite.

明治三十九年二月、祖母を衰ふ。年八十七。七月、ますます踺康を害ひ、 静養のため、逗子、田越に借家。一臬の假すまひ、やがて四年越の長きに瓦 れり。殆ど、枵と、じやが薯を食するのみ。十一月、「春畫」新小説に出づ。 うたたねに惁しき人を見てしょり夢てふものはたのみそめてき。雨は屋を漏 り、占軒に鳴き、風は粠の枝を折りて、棟の柿苜を貫き、破食の天井を刺さ むとす。腯の穗は霜寒き枕に散り、ささ蟹はむれつ>畳を走りぬ。「春畫後 刻」を草せり。蝶か、夢か、殆ど烧场の間にあり。李長吉は其の頃嗜みよみ たるもの。 ${ }^{78}$

Février 1906. Je perds ma grand'mère. Elle était dans sa quatrevingt-septième année. En juillet, mon état de santé s'aggrave encore ; pour ma convalescence, je loue une maison au lieu dit Tagoe à Zushi. Ce qui ne devait être que le séjour provisoire d'un été devient bientôt un lieu où je demeure plus de quatre années. Je ne me nourris que de gruau et de pommes de terre. En novembre Une Après-midi de printemps est publié dans Shin shösetsu. Depuis qu'en un sommeil / F'ai aperçu / Celui qui m'est cher / Aux rêves j'ai commencé à accorder confiance. La pluie transperce le toit ; un hibou ulule sous l'auvent, le vent brise les branches du keyaki, traverse le bois du faîtage et s'en vient frapper le dessus de la literie déchirée. Sous la morsure du froid et du gel, les épis des roseaux tombent sur mon oreiller ; en groupe les araignées courent sur les nattes du plancher. Je rédige Suite à Un après-midi de printemps. Un papillon? Un rêve? Je suis presque en extase. A cette époque, je lis avec délices Li Zhangji.

Le jeu des références faisant irruption dans le texte et le venant hanter est précisément le mécanisme que nous avons essayé, avec plus ou moins de fortune, de mettre au jour ici. Le poème d'Ono no Komachi 小野小町 - «Depuis qu'en

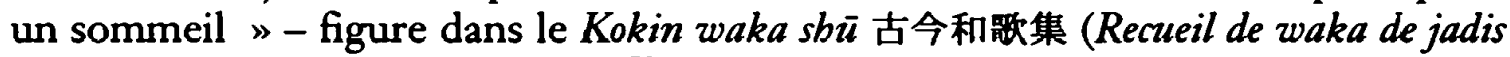
et d'aujourd'bui) au numéro $553 .{ }^{79}$ Il est dans la deuxième partie de la section intitulée " poèmes d'amour » (jp. koi.uta 慜歌) et comporte lui-même une référence à l'un des poèmes du Yutai xinyong 玉害新詠 (Nouveaux chants des

Kyōka (notamment J. Grossman, et G. C. Werlings). Le dernier vers fut le titre de la traduction anglaise de Scott-Moncrieff d'A l'ombre des jeunes filles en fleurs.

${ }^{78} K y o \bar{k} a$ zensbu $\bar{u}$ 鏡花全集, op. cit., vol. 1, p. ix.

${ }^{79}$ Kokin waka shü, éd. cit., p. 174. 
terrasses de jade) qui figure dans le livre II dans une série appelée «Poèmes d'amour » (ch. qingshi 情詩) : «Et en un somme, nos âmes ont leur commerce. J'y rencontre les formes de l'être qui m'est cher. 》麻假交精爽. 覞我佳人姿. ${ }^{80}$ Malgré le renversement des sexes - le poème, dans la série de Zhang Hua 張華 (232-300) est censé être composé par un homme, la frontière entre le songe et le réel, l'amour possible et impossible, la sensualité des vers, composent un univers sur lequel Kyōka va composer son récit en deux parties. Ce monde à la frontière est celui du mugen, dont nous avons exposé les linéaments plus haut.

Kyōka, lisant Li He à Zushi, compose une histoire avec un emboîtement des narrations, technique qu'il a depuis longtemps éprouvée et qui trouve dans $U n$ Après-midi de printemps l'un de ses avatars les plus complexes. Le personnage principal se promène près de Zushi à Kunoya, pour le reste du récit il est présenté au lecteur sous un nom générique : « le promeneur, l'errant » (jp. sansakushi 散策子). ${ }^{81}$ A ce personnage, venu en quête de lui-même en ces lieux reculés, une histoire va être rapportée par un moine bouddhiste, responsable d'un monastère en déclin, l'Iwato dera 岩殿寺. ${ }^{82}$ Celui-ci est dédié à Guanyin/Kannon 觀音菩薩. ${ }^{83}$ Le supérieur du monastère, après que le promeneur eut remarqué le poème d'Ono no Komachi que Kyōka cite dans son autochronologie, lui relate l'histoire d'une étrange noyade survenue l'année passée en été. L'homme qui fut victime de cette noyade, en fait un suicide déguisé, est un double du narrateur. Celui-ci, dans le récit onirique, ne doit sa survie qu'au sacrifice de ce prédécesseur et d'un autre jeune homme à la fin du livre. Ces doubles du narrateur sont l'une des caractéristiques de l'écriture chez.

${ }^{80}$ Nous suivons l'édition avec le commentaire de $\mathrm{Wu}$ Zhaoyi 呉兆宜, Yutai xinyong 玉 歖新詠, Taipei: Shijie shuju, 1956, rééd., 2001, p. 65.

${ }^{81}$ Parmi les études consacrées à ce texte, trois d'entre elles sont particulièrement signifiantes dans la perspective envisagée ici. Charles Shirō INOUYE, The Similitude of Blossoms, Cambridge et Londres: Harvard University Asia Center, 1998, p. 189-202 ; OKA Yasuo 岡保生, “Shunchū zengo »春惯前後 (Autour d'Un Après-midi de printemps), texte dans Izumi Kyöka, op. cit., p. 147-158 (la version originale de l'essai avait paru en 1978) et KASAHARA Nobuo 笠原伸夫, Izumi Kyöka. Erosu no mayu 泉鏡花ーエロスの蔽 (Izumi Kyōka. Le cocon de l'érotisme), Tōkyō: Kokubunsha, 1988, p. 181-206. Une subtile et élégante traduction anglaise de Charles Shirō Inoyue figure dans son volume de traductions de Kyōka, Japanese Gotbic Tales, Honolulu: University of Hawai'i Press, 1996, p. 73-140 ; commentaire p. 174-186.

${ }^{82}$ Le nom de ce monastère est d'ordinaire prononcé en lecture sino-japonaise : Ganden-ji. Fondé selon la légende par Gyōki 行基, le Vénéré principal est une statue de Guanyin aux Onze Faces. Le monastère est le second parmi les trente-trois monastères du pèlerinage du bodhisattva dans le Japon de l'est 坂東三十三所. Aujourd'hui il appartient à l'école zen Sōtō 曹洞.

${ }^{83}$ Sur le personnage de Kannon et ses corrélations avec le monde imaginaire en Extrême-Orient voir Chun-Fang YU, Kuanyin. The Chinese Transformation of Avalokitesvara, New-York: Columbia University Press, 2001 et notre compte rendu, Cabiers d'Extrême-Asie 12 (2001), p. 211-221. Voir également IYANAGA Nobumi 两永信 美, Kannon ben.yō dan 觀音寒容謨 (Récits des métamorphoses de Guanyin), Kyōto: Hōzōkan, 2002 et notre compte rendu dans ce numéro. 
Kyōka. L'homme mort de noyade tombe amoureux d'une femme à sa simple vue. Celle-ci, Tamawaki Mio, est l'épouse d'un riche marchand qui la méprise et ne fait aucun cas d'elle. Après une scène où le jeune homme amoureux se dirige vers la mort après la rencontre de femmes étranges au fond d'une vallée, dans une grotte - la Grotte des serpents (jp. ja no yagura 蛇の矢倉) ${ }^{84}$ il se noie volontairement en marquant le corps de l'hérö̈ne de trois signes : $\triangle \square \bigcirc$. Et Tamawaki Mio laisse sur les murs du temple le waka de Komachi. La seconde partie du texte s'articule cette fois-ci autour du personnage de Mio. Quel personnage est-elle donc ? Le moine la décrit ainsi au promeneur :

其の眉のか〉り、目つき、愛婍があると申すではない。口許など漯として、 世䱣を一つ言ふやうには思はれぬが、唯何んとなく貿げに、稿も無常も知り 拔いた風に見える。身體つきにも顔つきにも、情が滴ると言つた状だぢや。到

Je ne peux certes dire que la forme de ses sourcils, que son regard étaient charmants. Sa bouche d'une élégance tendue ne semblait pas capable de prononcer la moindre flatterie, elle avait simplement l'air de posséder une certaine intelligence, comme si elle avait pénétré les mystères de l'amour et de la vanité du monde. Les formes de son corps et celles de son visage semblaient exsuder le sentiment.

Une beauté mystérieuse. Celle de la personne qui a percé les arcanes de l'existence, pour son plus grand malheur sans doute. L'amour est mis en contraste avec l'impermanence. L'intelligence de la personne est à mettre en rapport avec la mélancolie qui la définit et la passion qu'elle inspire. Et, un peu plus loin, le moine décrit les charmes de Mio ; leur effet est le même que celui de bien des héroïnes de Kyōka, notamment celle de Kōya Hijiri :

慕はせるより、懷しがらせるより、人目見た男を魅する、力廣大。少か らず、地獄、極樂、娑婆も身に附絡うて居さうな婦人、從うて、罪も報も淺 からぬげに見えるでございます。

Ses pouvoirs étaient immenses : plus que de faire naître la langueur ou la nostalgie, elle ensorcelait un homme à sa simple vue. Pour le moins, c'était une femme qu'accompagnaient les enfers, le paradis, et ce bas monde. Il me semblait que ses fautes et les châtiments qu'elles engendraient n'étaient pas légers.

La dimension religieuse des $n \bar{o}$ est inscrite en filigrane dans ce texte où tous les événements se déroulent à la frontière des mondes. Mio dans la seconde partie

${ }^{84}$ Kyōka zenshū, éd. cit., vol. 10, p. 286. Le terme de yagura 谷倉 (Kyōka use d'une autre graphie), désigne une grotte artificielle aménagée sur le flanc d'une vallée et servant à conserver diverses choses. Il est ordinaire dans le parler des régions autour de Kamakura. La définition du Shögenjikō setsuyō shü dit : «Dans le dialecte des habitants de Kamakura, en la province de Sōshū (Sagami), le mot grotte se dit yagura. 》谷倉ヤグラ。 相州鎌倉俚民謂岩笛篇矢倉.

${ }^{85}$ Kyöka zenshü, op. cit., vol. 10, p. 263

${ }^{86}$ Id. p. 263-264. 
a un carnet où elle reproduit les mêmes motifs : $\triangle \square \bigcirc$. L'intersigne ${ }^{87}$ se reproduit, dans cette marche vers la mort, ce lamento que constitue la seconde partie, et les rencontres oniriques se poursuivent. Le texte, celui du poème d'Ono no Komachi, celui, tout autant significatif, du poème d'Izumi Shikibu 和 泉式部 dans la seconde partie, le poème de $\mathrm{Li} \mathrm{He}$ que cite le jeune homme mort de noyade, pour ne rien dire des trois signes du triangle, du carré et du rond qui évoquent les formes d'un mausolée funéraire (jp. gorintō 五輪塔), sont autant de malédictions, si l'on en juge par leurs effets ou, si l'on essaie de suivre la dialectique de Kyōka, de charmes qui traduisent l'efficace souveraine du verbe. La communion entre les vivants et les morts que permet le recours au rêve, à la fantasmagorie, à l'illusion dans les mugen nō, trouvent ici leur aboutissement.

Le texte se clôt sur une vision de coquillages. L'obsession de la trace, du vestige, de l'objet qui signale au lecteur à la fois la présence et l'absence sera l'os dans sa version marine. Le katami 形見, le "souvenir du mort », en sera la trace à jamais et marquera la borne entre le monde obscur et celui des vivants. Il est un support quasi chamanique de l'action qui s'est déroulée à la frontière et, également, le point où le passé pourra ressurgir. L'enfant d'une troupe de comédiens errants qui meure après que Mio lui a donné le poème, emporté par la lame et l'héroïne elle-même sont rejetés par les flots où ils ont quitté ce monde. Les deux corps à la surface de l'eau, celui de l'héroïne et de l'infortuné messager en charge de son poème, se trouvent incarnés dans cette forme à la frontière du monde minéral et du monde vivant.

どんなに潮に乳机たろう。渚の砂は、崩しても、積る、くぼぬば、たま る、音もせぬ。たぐ美しい骨が出る。貝の色は、日の紅、渚の雪、浪の碧。 ${ }^{88}$

Emporté par la marée, quel désordre dut être le sien ! Le sable du rivage, s'accumulant autant qu'il se défait, remplissant les creux dès qu'il les évide, sans le moindre bruit. Seuls des ossements magnifiques sortirent. La couleur des coquillages : l'écarlate du soleil, les neiges du rivage, le vert des vagues.

Quelle fin plus remarquable pour ce texte déjà si étrange ? Et la nature, fût-ce par le truchement des fantômes, des êtres surnaturels, des arbres ou des plantes est au cœur de l'écriture de Kyōka, comme elle l'était pour les auteurs de $n \bar{o}$ :

${ }^{87}$ Autour de cette notion de l'intersigne, entrée en littérature avec la fameuse nouvelle de Villiers de l'Isle-Adam réunie dans les Contes cruels (1867), pourrait s'écrire une histoire de la littérature fantastique dans sa relation avec les correspondances mystiques et magiques qu'elle entretient avec le monde, le grand livre du réel, dont elle sonde les énigmes. "Les intersignes annoncent la mort. Mais la personne à qui se manifeste l'intersigne est rarement celle que la mort menace. [...] Si nous étions moins préoccupés de ce que nous faisons ou de ce qui se fait autour de nous en ce monde, nous serions au courant de presque tout ce qui se passe dans l'autre ", Anatole LE BRAZ, La Légende de la mort chez les Bretons armoricains (première édition 1893), cité d'après la réédition figurant dans Magies de la Bretagne, Paris: Robert Laffont, coll. « Bouquins », 1994, p. 103.

${ }^{88}$ Ibid., p. 333-334. 
謡曲では、自然がシテで、人間がワキになつてみることが往々ある。例

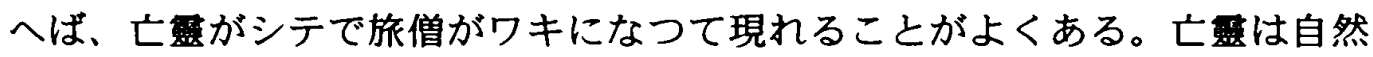
の変化したるものとして觀ることが出来ると思ふ。が、シテなる自然に重き を措いて、ワキなる人間を軽視するといふことが出来ない。何処までも兩者 融合せねばならぬと思ふ。89

Dans les pièces de $n \bar{o}$, il arrive souvent que la nature soit le shite et que les humains soient le waki. Ainsi, il est fréquent qu'un spectre apparaisse comme sbite et un moine itinérant comme waki. Il est possible de voir ce spectre comme une transformation de la nature. Mais il est impossible de traiter à la légère le personnage humain qu'est le waki en faisant peser l'importance sur la nature qui tient lieu de shite. Il me semble qu'une fusion constante des deux est toujours nécessaire.

Cette fusion de la nature et de l'être humain, ce hiéroglyphe final, se peuvent expliquer par une référence à un $n \bar{o}$ célèbre, $A m a$ 海士 (La plongeuse) ${ }^{90}$ que Kyōka réutilise, cette fois-ci au cœur de l'intrigue, dans Uta andon. L'héroïne est une femme qui a plongé dans l'abîme de l'océan pour en ramener une perle et ainsi assurer sa position à la cour. Mio, en remontant morte à la surface, incarne aussi, par son sacrifice, la nature de la mère salvatrice. Elle est chez Kyōka une parfaite incarnation de la femme, à la fois séductrice et dévoreuse d'hommes comme la magicienne dans Kóya bijiri, et une image de la mère du Buddha, de l'idéale grande sœur qui vient sauver les êtres par son sacrifice. Le crâne de Rohan et, les coquillages-ossements de Kyōka sont dans le récit autant de marques qui permettent la communication entre les vivants et les morts.

D'où l'extrême importance du thème sépulcral. Il se relie bien sûr, et de la façon la plus directe, à l'obsession du négatif : la tombe installe à l'intérieur des perspectives de la vie le rappel, donc le vertige de la mort (...) Dans le grand évanouissement des âges, elle constitue le seul appui valable de la pensée et de la rêverie. ${ }^{91}$

Déjà ébauchée dans nombre de ses récits et, plus tard, dans ses pièces, Un aprèsmidi de printemps permet à Izumi Kyōka, la même année où Hasegawa Tenkei donne son discours sur le bouddhisme et son absence de validité dans le monde moderne, notamment dans les lettres, de proposer une autre solution à cette querelle des images et du sens.

Au moine qui se lamente de la désaffection du public pour les lieux saints, du manque de rationalité de la religion qu'il est censé défendre, le promeneur, l'errant tient un discours qui n'est autre que celui de Kyōka, Rohan ne l'aurait sans doute point renié :

${ }^{89}$ Kyōka zenshūu, op. cit., vol. 28, p. 734. Le texte de Kyōka d'où cet extrait est tiré porte pour titre «Byōsha no shinka »描炰の缜 (La vraie valeur des descriptions). Il date de juillet 1909.

${ }^{90}$ Texte dans Yökyōku byakuban, op. cit., p. 573-580.

${ }^{91}$ Jean-Pierre RICHARD, Paysage de Chateaubriand, Paris: Le Seuil, coll. « Pierres vivantes », 1967, p. 26-27. 
偶像も同一です。唯偶像なら何でもない、此の御堂のは觀世音です、信 仰をするんでしょう。ぢや、偶像は、木、金、乃至、土。それを金銀、珠玉 で飾り、色彩を装つたものに過ぎないと言ふんですか。人間だつて、皮、血、 肉、五欌、六腑、そんなもので束ねあげて、是に衣ものを着せるんです。第 一貴下、美人だつて、たかがそれまでのもんだ。

しかし、人には眶魂がある、偶像にはそれがない、と言ふかも知れん。 其の、貫下、其の貴下、整魂が何だか分らないから、迷ひもする、悟りもす る、危みもする、安心もする、拜みもする、信心もするんですもの。 ${ }^{92}$

Il en va de même pour les idoles. Ne seraient-elles que des idoles, rien de grave. Mais ce pavillon est celui de Kannon, on y rend un culte. Alors, une idole est faite de bois, de métal ou, qui sait ?, de terre. Me direz-vous encore qu'on l'a simplement décorée d'argent, d'or et de perles et revêtue de couleurs ? Mais l'être humain est un assemblage de peau, de sang, de chairs, des cinq viscères et des six organes qu'on habille d'un vêtement ! Et d'abord, vous savez qu'une belle femme n'est pas plus que cela !

Mais, vous me rétorquerez peut-être que les humains ont une âme et les idoles non. Mais, vous savez, vous savez bien que l'on ignore ce qu'est l'âme ! Et donc, on erre, on obtient l'Éveil, on a des craintes, on est rassuré, on révère et on croit.

Les discours religieux de la modernité sur le bouddhisme se trouvent démentis dans ces lignes. Les images bouddhiques sont des icônes, le monde est réenchanté. La doctrine bouddhique de l'impureté des corps, méditée dans la beauté promise à la flétrissure des femmes, est la première marche du long escalier menant à la libération. Les fantômes, les songes, les rêves, le commerce avec l'au-delà, l'efficace des divinités et des cultes reprennent une vie qu'en fait, malgré les sons tonitruants des trompes annonçant la mort des dieux - et, par là, celle des hommes, elles n'avaient jamais perdue. Tout est toujours vivant, les individus sont dans ce cycle et ainsi ne meurent jamais. La scène du monde devient en son entier le lieu d'un mugen nō. La fiction de Kyōka est une fiction de la présence réelle.

Kyōka trouve dans Un après-midi de printemps le terme adéquat pour désigner l'enjeu de l'écriture, pour exprimer en un mot sa théorie du beau : le genius loci (jp. chiyō 地妖), plus exactement, la capacité de certains lieux à révéler leur part d'ombre, à agir comme des déclencheurs du surnaturel. Le terme a son origine dans les classiques chinois, mais c'est chez l'écrivain populaire d'Edo Takizawa Bakin 瀧澤馬琴 (1767-1848) que Kyōka le devait trouver : dans le soixante et unième chapitre du Cbinsetsu yumibarizuki 椿説马張月 (Histoire fantastique de la lune en croissant) (1807-1811), une vieille dame, par son zèle, symbole de la foi naïve des temps anciens a évité qu'un stūpa ne soit souillé de sang et ainsi que les lieux ne laissent place à leurs épouvantes. ${ }^{93}$ Ces sortilèges du lieu, le héros d'Un après-midi de printemps les perçoit avant même d'entendre le récit du moine, dans

${ }^{92}$ Kyōka zensbū, op. cit., vol. 10, p. 236-237.

${ }^{93}$ Texte dans Cbinsetsu yumibarizuki 椿説弓張月, Tōkyō: Iwanami shoten, coll. «Nihon koten bungaku taikei », 1962, p. 338. 
le triangle que forment trois figures animales présentes dans la montée vers le

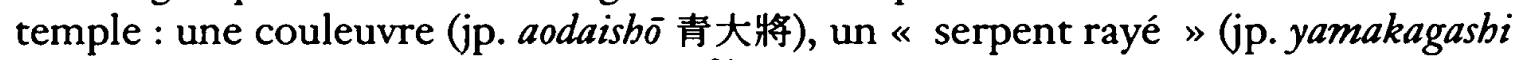
赤棟蛇) et trois chevaux côte à côte. ${ }^{94}$ Ces phénomènes étranges que les lieux possèdent et qu'il sont encore capables de faire revivre pour nous par l'écriture sont, sans doute, l'expression la plus pure des pouvoirs ineffables du langage. Ces mêmes pouvoirs qui, associés à l'acte conjuratoire de la danse dans les nō et à la récitation des textes bouddhiques, permettent à l'écriture de devenir le suprême acte de nécromancie. Comme Rohan dans Tai dokuro et dans d'autres récits de ses débuts, mais sans doute avec plus de constance, Kyōka, par sa relecture du passé, a fait de la littérature un véritable Dialogue des morts. Mais celui-ci fondé sur la survivance permanente du passé, sur son interaction avec le présent. A l'image des textes de $n \bar{o}$, les récits de Kyōka sont une liturgie de la parole pour réconcilier les vivants et les morts.

\section{Conclusion}

Les textes que nous avons analysés ici ne sont qu'une partie de ceux qui, chez Rohan et Kyōka, ont placé la réflexion sur le bouddhisme en leur centre. Rohan reviendra sur les légendes bouddhiques dans plusieurs de ses récits. Après Fürryü butsu, il composera notamment deux textes dans lesquels le bouddhisme joue un rôle central : le premier récit de Futsuka monogatari 二日物語 (Histoire de deux journées) (1892), ${ }^{95}$ qui décrit la rencontre de Saigyō 西行(1118-1190) et de l'empereur maudit Sutoku 崇徳 (1119-1164), ct le récit de la vie de Yoshishige no Yasutane 慶滋保扸 (mort en 1002) dans Renkan ki 連環記 (Mémoire des anneaux enchaînés) (1940) ${ }^{96}$ Le premier de ces deux textes revient dans sa première partie sur le $n \bar{o}$ Matsuyama tengu 松山天狗 (Les démons ailés de Matsuyama) ${ }^{97}$ et la première des nouvelles de l'Ugetsu monogatari, Shiramine 白峯, articulée autour du rêve de Saigyō voyant l'empereur défunt ${ }^{98}$ Rohan, prenant de plus en plus l'attitude de l'antiquaire, va continuer à se plonger dans les discours savants, qu'il reconstituera sous une forme unique dans ses essais. S'il a avancé à rebours de son temps, la forme de l'essai et de l'étude, celle du commentaire pour les Sept recueils de Bashō 芭蕉七部集 et celle de la traduction pour le Shuibuzbuan 水海傅 (jp. Suikoden), ont peu à peu remplacé celle de la fiction.

Rohan revint toutefois sous une forme détournée vers le fantastique et le monde du rêve dans plusieurs œuvres composées dans ses dernières années,

\footnotetext{
${ }^{94}$ Kyöka zenshī, op. cit., vol. 10, p. 224.

95 Texte dans Roban zenshū Iwanami shoten, 1941, rééd. 1978, vol. 5, p. 545-561.

96 Texte dans Roban zenshü, op. cit., vol. 6, p. 489-564.

${ }^{97}$ Voir l'ouvrage de YAMADA Yūji 山田雄司, Sutokuin onryō no kenkyū 崇徳陵怨昰の研究 (Etude sur l'âme courroucée de l'empereur retiré Sutoku), Kyōto: Shibunkaku, 2001, notamment p. 3-63.

${ }^{98}$ Voir NAGASHIMA Hiroaki 長岛弘明, Ugetsu monogatari no sekai 雨月物語の世界(Le monde des Contes de la lune vague après la pluie), Tōkyō: Chikuma shobō, coll. «Chikuma gakugei bunko », 1998, p. 59-88.
} 
notamment dans une série de textes à la frontière de la fiction, du récit historique et de l'essai. Mentionnons simplement trois d'entre eux, Kanga dan 觀畫談 (Histoire de la vue d'un tableau) composé en 1925, Mabō shugyōsha 魔法 修行者 (Ceux qui pratiquent la magie) qui date de 1927 et, enfin, son dernier chef-d'œuvre du genre : Gendan 幻談 (Une histoire d'illusion), composé en 1938. Le héros de Kanga dan, dans un monastère où il s'est retiré pour soigner ses nerfs et sa santé délicate, suite à la contemplation d'un tableau, se trouve plongé à l'intérieur de celui-ci. Après avoir franchi les apparences, il revient dans le monde mais, comme les moines éminents dans les anecdotes bouddhiques, il est détaché des soucis du commun et il disparaît dans la nature sauvage en renonçant à mener la vie d'un étudiant moderne dans les grandes villes, retrouvant ainsi, trente ans après, la beauté et la noblesse du renoncement au monde et à la société du vulgaire (jp. datsuzoku 脱俗). Le monde du mugen a réanchanté sa vie, lui a donné un nouveau regard sur le monde. Tout est désormais changé.

Kyōka, en revanche, ne renonça jamais. La forme trouvée dans les $n \bar{o}$, avec leur esthétique du mugen et la structure circulaire du temps faisant de la littérature un acte conjuratoire absolu, trouve un aboutissement dans sa dernière œuvre : Rukō shinsō 縷紅新草 (Nouvelles pousses d'ipomée), publiée en juillet 1939. Depuis un an Kyōka n'avait rien publié : une première dans sa vie d'artiste. Son dernier récit est organisé autour de la visite aux morts. Un acte ultime et merveilleux de réussite de nécromancie littéraire. Un personnage qui apparaît déjà dans Usu kōbai 薄紅梅 (Pâles fleurs de prunus), l'écrivain Tsujimachi Itoshichi 辻町絲七 se rend sur la tombe de sa cousine Okyō お京, morte récemment et dont il avait été épris. Sa fille, Oyone お米 qui est le dernier avatar de la femme idéale selon Kyōka, mais dépourvue de tout côté inquiétant contrairement à la magicienne des montagnes et à Tamawaki Mio, lui inspire des sentiments très forts. Mais l'amour est impossible : Tsujimachi est trop vieux et il le sait. Oyone est d'ailleurs mariée. Il se trouve dans la position de l'oncle âgé, pourtant il n'en admire pas moins les charmes d'Oyone qui lui rappelle tant Okyō. Parmi les tombes, Oyone lui suggère que celle à qui il brûle de rendre les hommages dus aux morts n'est pas Okyō mais une femme à qui il doit beaucoup plus : Hatsuji 初路 (les caractères signifient le premier chemin, avec cet écho sombre du chemin que nous ne prîmes pas) qui, alors qu'Itoshichi cherchait à mourir, se suicida à sa place en se jetant dans les douves du château, lui, trop lâche, ne la rejoignant pas dans la mort. Elle était de très bonne famille et, tombée dans l'infortune, elle travaillait dans une fabrique de mouchoirs. L'une de ses compositions, qui présentait deux libellules (jp. akatonbo 赤蜻蛉) entrecroisées dans leur vol, fit l'objet de quolibets et d'une chanson ironique la fustigeant, ce qui la conduisit au suicide. Okyō, la mère d'Oyone, sait tout du passé d'Itoshichi, qui vécut sans remords jusqu'à ce jour. Trois femmes se mêlent ici dans le texte : la belle Oyone, la compréhensive et compatissante Okyō et la tragique figure de Hatsuji. Ceux qui étaient jaloux de son talent de brodeuse, donnent à Hatsuji une tombe sans nom, lui refusant le respect même dans la mort. La ville de Kanazawa décide 
bien plus tard de lui donner une sépulture, mais celle-ci est un moyen de favoriser le tourisme plus que de commémorer sa mémoire. Les ouvriers qui sont en train de malmener sa pierre tombale, le vrai corps mystérieux de Hatsuji, sont effrayés par l'apparition de deux libellules, spectres qui font revivre le passé dont ils constituent la cicatrice toujours vive. De cette miraculeuse tombe émane un parfum d'une ineffable suavité. Enfin, Oyone la revêt de son vêtement, montrant qu'à terme, dans ces mondes où les rêves le disputent au triste réel, elle est l'incarnation de l'idéal féminin, dépouillé de ses initiales terreurs mais qui n'est plus que compassion. Alors qu'elle redescend avec Itoshichi vers la ville, le texte se clôt sur une scène qui est sans doute parmi les plus belles écrites par Kyōka :

大城下は、目の下に、町の燈は、川に柳にともれ流る〉。磴を下へ、谷 の暗いやうに下りた。場末の五燈はまだ來ない。

あきなひ歸りの豆腐屋が、ぶつかるやうに、ハ夕と留つた時。

「あれ蜻蛉か。」

お米が膝をついて、手を合せた。

あの墓石を寄せかけた、塚の絲枠の柄にかけて下山した、提灯が、山門

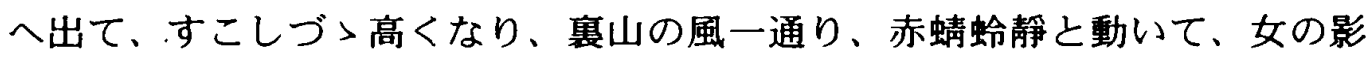
が...... 二人見えた。 ${ }^{99}$

La ville fortifiée était sous leurs yeux, ses lumières allumées dansaient sur la rivière entre les saules. Ils descendaient les marches de pierre vers les ténèbres profondes comme une vallée. Les esprits des faubourgs n'étaient pas encore venus.

Il s'arrêta comme si un vendeur itinérant de tōfu lui était rentré dedans.

- Ah! Des libellules?

Oyone tomba à genoux et joignit les mains.

La lanterne de papier qu'ils avaient laissé accrochée sur les fils du mausolée où ils avaient posé la pierre tombale, franchissant le portail du monastère, s'était élevée légèrement dans les airs ; elle fut emportée par un souffle de vent venu de derrière. Deux libellules se mouvaient avec douceur. Ils virent... l'image de deux femmes.

Ce passage est celui qui évoque avec le plus de délicatesse, de beauté où ne se mêlent point de sentiment de terreur et d'effroi, les spectres de Zeami et la tradition du mugen nō dont nous avons parlé dans les pages qui précèdent. C'est Yukio Mishima qui sut reconnaître avec le plus de talent la valeur de ce texte. C'est lui qui parvint à le lire avec la plus profonde compréhension de l'univers qui l'avait engendré.

「維紅新草」は、昼間の空にうかんだ燈箱のように、清澄で、栬やかで 細緻で、いささかも土の污れをつけず、しかもまだ燈されない、何かそれ自 體無意味にちかいような果敢無さの詩である。これも、能に似た氣分を持っ た作品で、三十年前の心中事件は思い出の彼方へ融け入り、今、小春日和の

${ }^{99}$ Kyōka zenshü, op. cit., vol. 24, p. 717. 
午後の展墓にいそぐ美女と初老の男の心に、事件は幽要の蜻蛤によつて、 淡々とよみがえってくる。 ${ }^{100}$

Comme une lanterne flottant dans le ciel diurne mais point allumée encore, Nouvelles pousses d'ipomée est une poésie pure, sensuelle et attentive aux détails, qu'aucune salissure terrestre ne vient entacher, toute d'éphémère et de fragilité, presque dénuée de sens en elle-même. De plus, l'œuvre possède une atmosphère proche des $n \bar{o}$; l'affaire vieille de trente ans du double suicide se fond au-delà des souvenirs, aujourd'hui, dans le cœur d'un homme au seuil de la vieillesse et celui d'une jolie femme se hâtant pour une visite aux tombes ; elle ressurgit avec une infinie douceur sous la forme de spectrales libellules.

Mishima, qui voulait être un nouveau Kyōka, au moins dans l'écriture, mais qui aurait préféré aux princesses des montagnes Apollon et Dorian Gray, comprit, dans sa lecture de Kyōka, la magie du verbe qui permettait de faire affleurer ces êtres surnaturels dont la beauté se trouvait jetée à la figure du monde moderne et du règne de la laideur qu'il entendait proposer. Ces rêves du plein jour dont l'attraction était forte comme un drapeau, pour les faire comprendre, il les renvoie au Füshi kaden 風姿花傳 de Zeami. Le vieil acteur est pour Mishima une métaphore de Kyōka et comme celui-ci, il reste celui qui a obtenu la véritable fleur, la quintessence de son art que les ravages du temps ne sauraient flétrir. L'héritage des maîtres de $n \bar{o}$ était dans ce miracle de la survie et de la floraison, en doubles fleurs rouges comme l'ipomée, de la sorcellerie du verbe et de son cortège de fantômes.

Pour mieux comprendre les enjeux de ces tentatives de réappropriation du passé et de réanchantement du monde entrevues dans cet essai, Akutagawa Ryūnosuke 芥川龍之介(1892-1927) est le meilleur des témoins. Il écrivit dans la préface aux Euvres complètes de Kyōka un texte fondamental pour comprendre les clefs de l'esthétique de l'auteur. Akutagawa insiste sur ce qui distingue Kyōka des autres écrivains. Il y voit avant tout la notion d'éthique (jp. rinrikan 倫理観), fondée non sur les valeurs de la société, mais sur celles du cœur. Kyōka défend et illustre, avant toute autre chose, la « justice poétique » (jp. shiteki seigi 詩的正義).

のみざらずこの倫理觀は先生の愛する超自然的存在、一幽捄や妖怪にも 及んでるる。尤も先生の初期の作品は必ずしも惡暑を避けなかった譯ではな い。「湯女の魂」の蝙蝠の如きはこの惡孁の尤なるものである。しかしその 後の超自然的存在はいつか倫理的に向上した。101

Non seulement cela, mais ces conceptions éthiques s'étendent également aux êtres surnaturels - spectres et monstres que Kyōka aimait.

${ }^{100}$ Cet essai magistral de Mishima accompagne le volume Ozaki Kōyō, Izumi Kyōka 尾椅 紅莱・泉鏡花, Tōkyō: Chūōkōronsha, 1969, nous citons d'après le volume Sakka ron 作家論 (Critiques sur divers auteurs), Tōkyō: Chūōkōronsha, coll. « Chūko bunko », 1974, p. 38.

101 Texte dans Akutagawa Ryünosuke zenshū (Euvres complètes d'Akutagawa Ryūnosuke) 芥川能之介全集, Tōkyō: Iwanami shoten, 1996, vol. 12, p. 204. 
Certes, les œuvres de sa première époque n'ont pas toujours évité les esprits maléfiques. La chauve souris de L'âme de la femme des bains est le plus bel exemple de ces mauvais esprits. Mais, dans les œuvres ultérieures, ces êtres surnaturels se sont élevés au niveau éthique.

Kyōka se situe dans la tradition japonaise du fantastique, mais s'il faut parler de ses œuvres, alors Akutagawa en rappelle l'archétype idéal :

われわれの文學は「今昔物語」以來、超自然的存在に乏しい譯ではない。 且また近世にも「雨月物語」等の佳作のあることは事宾である。けれども淁 曲の後ジテ以外に誰がこの美しい威㙰を彼らに與えたであろう。102

Nos lettres nationales, depuis les Histoires qui sont maitenant du passé, ne manquent pas d'êtres surnaturels. De plus, il est vrai qu'il y a, à l'époque Edo, des chefs-d'œuvre du genre comme Les contes de la lune vague après la pluie. Mais, en dehors du nocbijite des pièces de nō, qui a pu leur [aux êtres surnaturels] conférer une telle majesté ?

Akutagawa, parlant du style de Kyōka, continue dans cette comparaison. Il sait que cette "justice poétique " doit aussi beaucoup aux pouvoirs d'enchantement du verbe. Chez Kyōka, il mêle les formes de la langue écrite et de la langue parlée, du fonds classique et de l'héritage chinois. Là encore, à qui le comparer ?

若し、他に匹を求めるとすれば、恐らくは謠曲を獨造した室町時代の天 才だけであらう。

S'il fallait chercher avec qui le mettre en parallèle, il n'y aurait sans doute que les génies de l'époque Muromachi (1392-1573) qui inventèrent et conçurent les pièces de $\boldsymbol{n} \bar{o}$.

Les rencontres de plusieurs types d'imaginaire analysées dans ces pages bouddhisme et écriture de fiction, héritage classique et récits modernes, rêves et réalité, ont sans doute trouvé leur forme privilégiée dans l'héritage du $n \bar{o}$ tel que le remirent en vigueur Rohan et surtout Kyōka. Il demeure le point de départ privilégié pour une lecture attentive du fantastique à l'époque moderne. La belle femme spectrale, l'âme errante parmi les montagnes, les sortilèges de la chair et de son dépassement sont autant de motifs qui, s'ils se joignent au cortège des voix réclamant une redécouverte de la part d'ombre parfois ignorée par les tenants du mainstream en matière littéraire, constituent néanmoins une invitation à relire, à la lumière du passé et de ses formes d'expression, les relations entre le bouddhisme japonais et la littérature. La leçon de ces textes est un appel à une redécouverte de cette capacité pour l'étonnement, pour la merveille : " toute vue des choses qui n'est pas étrange est fausse ». ${ }^{103}$ Les territoires du rêve, mais aussi ceux des fantômes sont avant

102 Id. p. 205.

${ }^{103}$ Voir l'exégèse de ce slogan sur un mur en 1968 dans le beau livre de la médiéviste Caroline WALKER BYNUM, Metamorphosis and Identity, New York, Zone Books, 2001, p. 37-75. « ... For the flat, generalizing, presentist view of the past encapsulates it and 
tout ceux du cœur humain et de l'inconscient. Subtilement présents à l'horizon des grandes pièces de Zeami et de son art, ils sont aussi au centre de l'esthétique des auteurs modernes ici étudiés. Kyōka en fut le dernier garant, comme le disait justement Mishima. ${ }^{104}$ La présence des morts, leur interaction avec les vivants, le retour de la liturgie de la parole, l'imaginaire de la frontière sont autant de pistes de réflexion pour comprendre un des nombreux et passionnants visages des lettres modernes au Japon dans leur relation avec le monde des classiques, revenus de la poussière du temps. ${ }^{105}$ Les textes examinés ici furent les précurseurs d'un âge d'or du fantastique dans la littérature moderne au Japon. Ils trouvèrent leur moment faste dans les années vingt du vingtième siècle, soit vingt et trente ans après leur publication. Un florilège de récits étranges assurèrent alors un véritable été indien au genre. On peut mentionner les contes fantastiques d'Akutagawa Ryūnosuke, ${ }^{106}$ d'Okamoto Kidō 岡本綺堂 (1872-1939), de Tanizaki Jun.ichirō

makes it boring, whereas amazement yearns toward an understanding, a significance, that is always just beyond both our theories and our fears. Every view of things that is not wonderful is false », p. 75.

${ }^{104}$ Sur ce rôle des démons du cœur (jp. kokoro no oni 心の鬼), voir MORI Masato, «Kokoro no oni no hongi» 心の鬼の本義 (Le sens originel de l'expression le démon du cœur», Bungaku 文學, 2001, numéros de juillet-août et de septembre octobre. Il y a, bien sûr, toute une étude à mener sur les prolongements de cette notion dans la littérature médiévale et pré-moderne.

105 Nous empruntons cette belle expression à Ray Bradbury, From the Dust Returned, New York: William Morrow, 2001.

${ }^{106}$ Ainsi Yōba 妖婆 《L'étrange vieille 》 (1919) définit la présence du fantastique dans le Japon de la démocratie de Taishō : "Sans doute ne croirez-vous pas ce que je vous raconte. Non, vous penserez au contraire que c'est un mensonge. Les choses d'autrefois : je ne les connais pas ; mais ce que je vais vous raconter maintenant se passe à l'époque éclairée de Taishō. De plus, les faits se sont produits dans ce Tōkyō où vousmême êtes habitués à vivre. On sort dehors et l'on voit passer les trains et les voitures. Dedans, la sonnerie du téléphone ne connaît pas de trève. Dans les journaux on est informé des grèves et des mouvements féminins. En une pareille époque, dans un coin de cette immense capitale, j'aurais beau vous dire qu'une terrifiante affaire digne de figurer dans les récits de Poe et d'Hoffmann s'est produite, vous ne me croirez pas et vous aurez raison（あなたは私の申し上ける事を御信じにならないかも知れません。いや、きつと嘘だと 御思ひなさるでせう。昔なら知らず、これから私の申し上げる事は、大正の昭代にあつた事な のです。しかも御同梾住み慣れてるる、この東京にあつた事なのです。外へ出れば晻車や自動 車が走つてるる。内へはいればしつきりなく電話のベルが鳴つてるる。新閶を見れば同盟罯工 や婦人運動の報道が出てるる。 さう云ふ今日、この大都会の一隅で、ポオやホフマンの小説 にでもありさうな、策味の惡い事件が起こつたとい云ふ事は、いくら私が事寞だと申した所で、 御信じになれないには御尤もです。). Texte dans Akutagawa Ryünosuke zenshū, op. cit., 5, p. 99. Le monde est bien réenchanté et la suite de la nouvelle se charge de le rappeler : " Mais, dans les quartiers de Tōkyō les lumières ont beau se compter par millions, elles ne peuvent balayer de leur incendie la nuit qui descend son voile dès que le jour décline et la transformer en lumière de midi. De manière rigoureusement similaire, le télégraphe sans fil et les avions ont peut-être conquis la nature, ils n'ont pu déployer la carte du monde mystérieux qui se tient tapi dans ses profondeurs »(が、その東京の町々の燈火が、 
谷崎潤一郎 (1886-1965), de Murō Saisei 室生犀星 (1889-1962), d'Uchida Hyakken 内田百閒 (1889-1971) et de Satō Haruo 佐藤春夫 (1892-1964) ; enfin la somme - tératologique - de Tanaka Kōtarō 田中貢太郎 (1880-1941), le Nihon kaidan zenshū 日本怪談全集 (Somme des récits fantastiques du Japon). ${ }^{107}$ Cette explosion des récits fantastiques devait beaucoup à la relecture des textes classiques, elle se fit aussi avec les traductions des chefs-d'œuvres anglo-saxons du genre. ${ }^{108}$ Dans ces divers récits revivent les héritages du fantastique traditionnel, mais leur incarnation la plus subtilc, lcur message le plus actuel se trouvaient dans ces «nō modernes » que Rohan et Kyōka avaient conçus. La libération qu'ils promettaient à leurs lecteurs, à travers les mille et un jeux du langage porté à son point d'incandescence, ces pivoines qu'ils faisaient éclore à brassées dans les déserts de la modernité, et cette nouvelle vie insuflée à leurs textes par la méditation du monde des pièces de nō les faisait rejoindre un autre de leurs contemporains de l'autre côté du monde ; lui maintenait que le vrai esclave est celui qui, de par son matérialisme, s'interdit de croire aux contes de fées : c'était Gilbert Keith Chesterton (1874-1936). ${ }^{109}$

Assurément, ce n'est pas sans raison qu'un crâne couleur de peau occupe le point central du septième jardin, sur une mare de liquide verdâtre aussi dense que du mercure, puisque l'ossement capital y flotte et que celle qui feint de se baigner s'y appuie et ne mouille pas ses mains qui jouent avec des vaguelettes de clarté. Une fille dévêtue sur un semblant de cheval de rivière un peu enfoncé, lui, tourne la tête pour ne pas voir sa compagne qui dans un jardin antérieur l'eût aimée peut-être, avant de chercher la figure de son ultime heure dans les traits du crâne charnel. N'est-ce le nom de Pompéi, ou un écho, qui va s'éteindre sous un couvert de pins parasols?

幾百萬あるにしても、日没と共に蔽いか〉る夜を悉燒木払つて、書に返す㩐には行きますまい。 丁度それと同じやうに、無線電信や飛行機が、如何に自然を征服したと云つても、その自然の 奥に潛んでるる神秘な世界の地圖までも、引く事が出来た次第ではありません。), id., p. 99. La carte d'état major ne saurait régner dans ce monde qui, grâce à Rohan et Kyōka, est réenchanté pour de bon.

${ }^{107}$ Premières éditions du texte en quatre volumes, Tōkyō: Kaizōsha, 1924 et 1929. Edition moderne en cinq volumes sous le titre Nihon kaidan taizen 日本怪談大全 (Somme des récits fantastiques du Japon), Tōkyō: Kokusho kankōkai, 1995.

${ }^{108}$ Anthologie de ghost stories dans la traduction de Saijō Ryūji 西条隆治, Kizetsu kaizetsu yūrei no hanashi 奇絶怪絶幽曋の話 (Histoires de fantômes étranges et fantastiques), première anthologie du genre en japonais en 1921 ; un second volume marquant de traductions est celui qui parut en 1929 sous la direction d'Okamoto Kidō, Sekai kaidan meisaku shū 世界怪談名作集 (Histoires fantastiques du monde entier). Akutagawa, avec son goût d'aficionado du genre laisse plusieurs essais sur le sujet. Dans la perspective de cet article, lire Chikagoro no yürei 近頃の幽急 (Spectres récents), texte de 1921. Voir Akutagawa Ryūnosuke zenshü, op. cit., vol. 7, p. 174-179.

109 Orthodoxy (1908), réédition Thirsk: House of Stratus, 2001, p. 7. Sur le fantastique et l'épouvante comme conte de fées modernes voir les propos éclairants du réalisateur Tim Burton dans le livre de David J. SkAL, The Monster Show. A Cultural History of Horror (1994), rééd. 2001, New York: Faber and Faber, p. 397. 
Que savons-nous, sinon que les jardins fabuleux de Yamashita sont habités exclusivement par la chaleur, le silence, la non-communication, la nudité de la femme, le serpent et la mort ? ${ }^{110}$

110 André Pieyre De Mandiargues, «Sept jardins fantastiques » dans Gris de Perle, Paris, Gallimard, 1993, p. 90. 